









\section{STATE OF FLORIDA}

\section{DEPARTMENT OF ENVIRONMENTAL PROTECTION \\ Noah Valenstein, Secretary}

REGULATORY PROGRAMS

John Truitt, Deputy Secretary

FLORIDA GEOLOGICAL SURVEY

Jonathan D. Arthur, State Geologist and Director
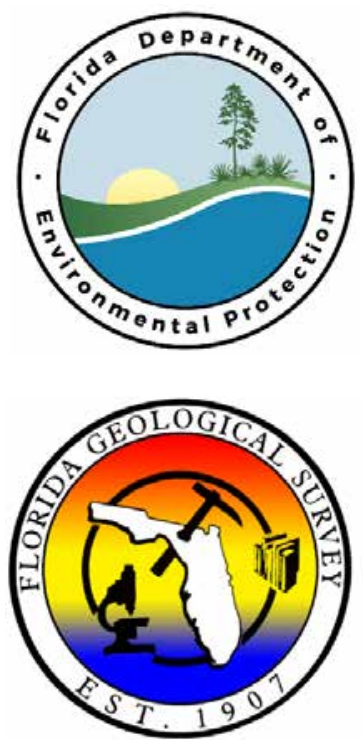

OPEN-FILE REPORT 106

Text to accompany geologic map of the

USGS Saint Petersburg 30 x 60 minute quadrangle, west central Florida

By

Richard C. Green, P.G., Brianne Apolinar, Christopher P. Williams, Katherine M. White, Seth W. Bassett, and Livia F. Nason

2017

ISSN (1058-1391)

This project was funded in part by the USGS National Cooperative Geologic Mapping Program under assistance award number G16AC00295 in Federal fiscal year 2016 



\section{TABLE OF CONTENTS}

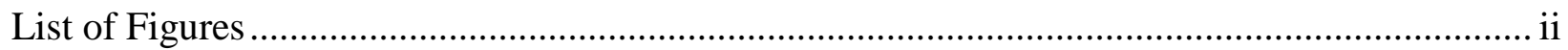

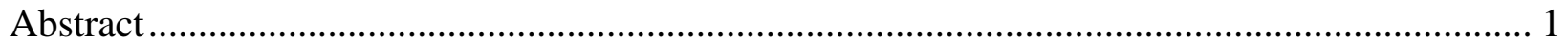

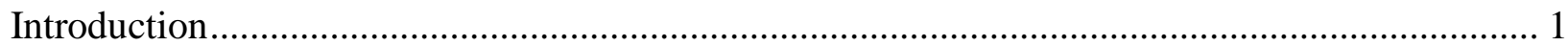

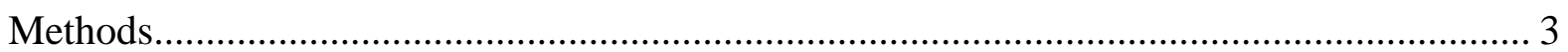

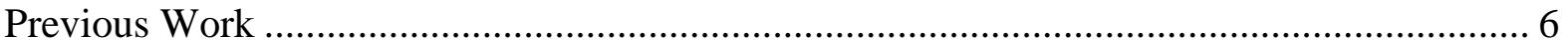

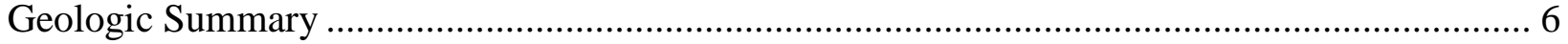

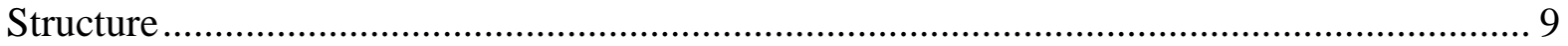

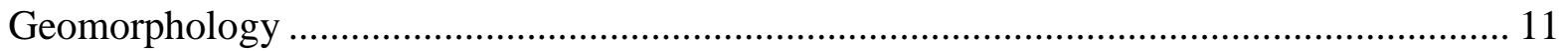

Ocala Karst District................................................................................................ 12

Land O’ Lakes Karst Plain..................................................................................... 13

Peace River District …………………………………….............................................. 13

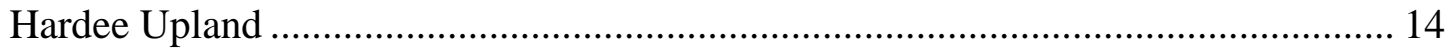

Peninsula Coastal Lowlands .............................................................................. 14

Pinellas Ridge ................................................................................................. 15

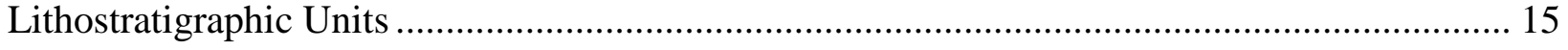

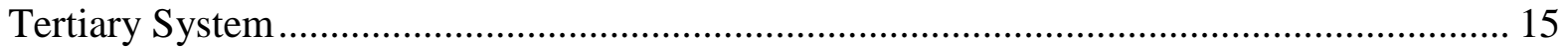

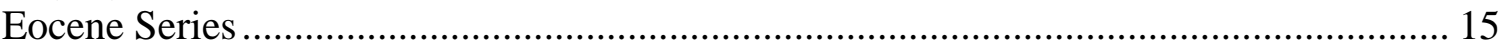

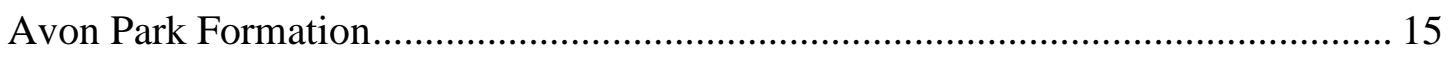

Ocala Limestone ............................................................................................... 16

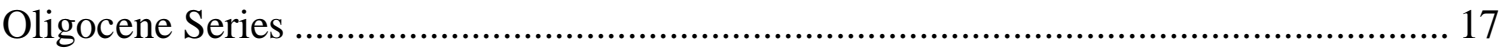

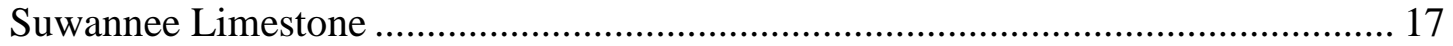

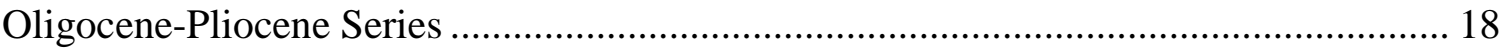

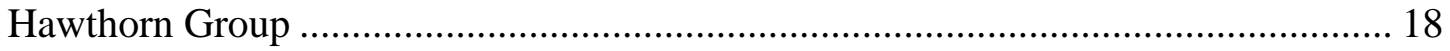

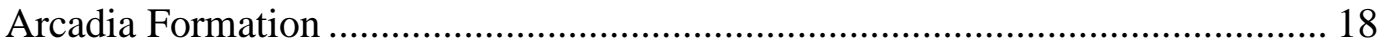

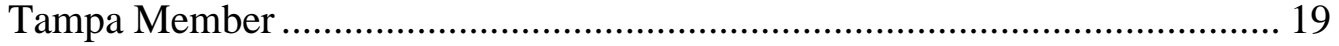

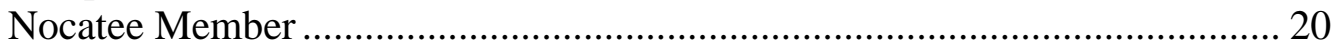

Peace River Formation...................................................................................... 20

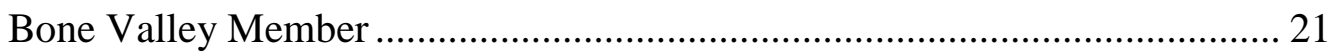

Hawthorn Group (undifferentiated) ........................................................................... 22

Tertiary/Quaternary Systems ............................................................................................ 23

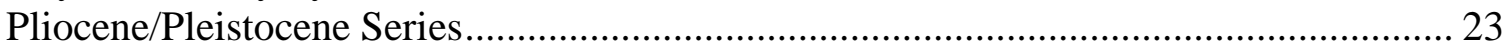

Undifferentiated Tertiary/Quaternary shelly sediments............................................... 23

Pleistocene to Holocene Series ....................................................................................... 24

Undifferentiated Quaternary sediments .................................................................. 24

Holocene sediments ...................................................................................... 24

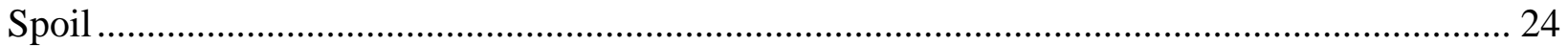

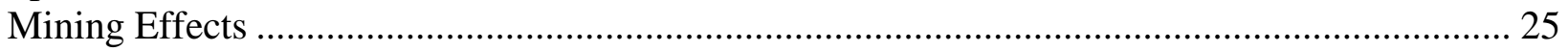

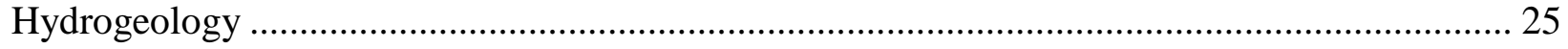

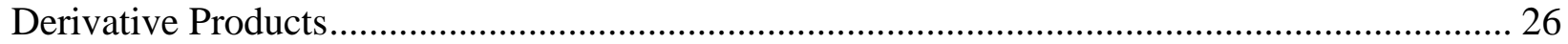

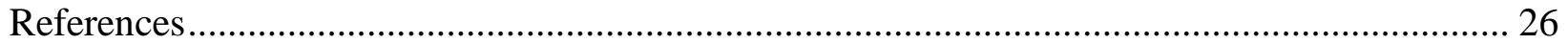

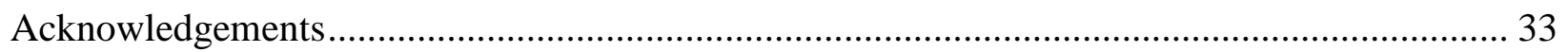

Appendix A: Florida Geological Survey Wells Utilized for Study ............................................... 35 


\section{LIST OF FIGURES}

Figure 1. Nearby areas mapped under the FGS STATEMAP Program ....................................... 2

Figure 2. FGS cores, cuttings, and M-series samples used for models ..................................... 3

Figure 3. Boxplot of top of lithostratigraphic unit elevation ranges........................................ 5

Figure 4. Location of selected river basins, springs, and other water bodies. ............................. 8

Figure 5. Principal subsurface structures of the Florida peninsula (modified from Arthur et al.,

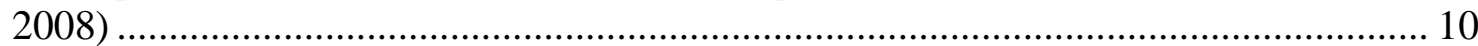

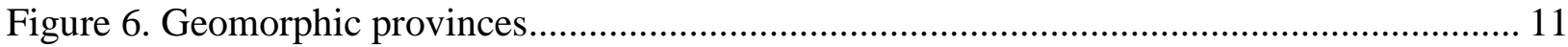

Figure 7. Mined areas with extents of Bone Valley Member from Arthur et al. (2008) .............. 22 


\title{
Text to accompany geologic map of the USGS Saint Petersburg 30 x 60 minute quadrangle, west central Florida
}

\author{
Richard C. Green (P.G. \# 1776), Brianne Apolinar, Christopher P. Williams, \\ Katherine M. White, Seth W. Bassett, and Livia F. Nason
}

\begin{abstract}
The accompanying 1:100,000 scale geologic map (Open-File Map Series 109, Plate 1) depicts the areal distribution of bedrock and surficial geologic units for the U.S. Geological Survey (USGS) Saint Petersburg 30 x 60 minute quadrangle. The map was constructed using a combination of field mapping (at 1:24,000 scale), compilation of data from existing maps (various scales), core and cuttings analyses and descriptions, and analyses of various Geographic Information System (GIS) data sources. The resulting data were compiled in ESRI ${ }^{\circledR}$ ArcGIS $^{\circledR}$ ArcMap $^{\mathrm{TM}}$ 10.3.1 software for publication as part of the Florida Geological Survey Open-File Map Series. Mapped units range in age from late Oligocene to late Holocene. Important resources in the mapped area include potable groundwater, springs, sand, clay, phosphate, shells, and limestone. Numerous springs and karst features are present in the study area.

The geologic map and accompanying plates produced for this area not only provide a greater understanding of the interaction between the geologic units, associated karst, springs, and ecosystems, but have utility as a land management tool for economic development, mineral and energy production, and environmental protection for Florida. Examples include designing new construction projects, siting new water supply wells, energy production facilities, waste management and storage facilities, locating sources of mineable resources, and protection of springs, surface and groundwater quality.
\end{abstract}

Keywords: Florida, geologic map, Avon Park Formation, Ocala Limestone, Suwannee Limestone, Hawthorn Group, Arcadia Formation, Tampa Member, Nocatee Member, Peace River Formation, Bone Valley Member, geomorphology, hydrogeology, springs, swallets, karst, sinkholes, Floridan aquifer system, Tampa Bay, Hillsborough Bay, Hardee County, Hillsborough County, Manatee County, Pinellas County, and Polk County.

\section{INTRODUCTION}

Florida Geological Survey (FGS) Open-File Report (OFR) 106 accompanies Open-File Map Series (OFMS) 109, which is comprised of three plates. Plate 1 depicts the near-surface geology of the USGS Saint Petersburg 30 x 60 minute quadrangle (U.S. Geological Survey, 1981) on a digital elevation model (DEM). This DEM is a composite derived from light detection and ranging (LiDAR) where it was available and elevations from USGS topographic quadrangles covering the mapped area where LiDAR was not available. Plate 2 depicts six geologic crosssections, along with a correlation chart of the stratigraphic units in the study area. Plate 3 is a geomorphology map on a DEM, showing locations of known springs and subsidence incident reports (SIRs), along with a detailed LiDAR image of a portion of Tampa Bay.

The study area lies south of Tarpon Springs and north of Sarasota. It includes the communities of Clearwater, Largo, Pinellas Park, St. Petersburg, Sun City, and Tampa. It also includes portions of Hardee, Hillsborough, Manatee, Pinellas, and Polk counties (Figure 1). It is bounded to the north by the USGS Tarpon Springs 30 x 60 minute quadrangle, previously mapped 
under the STATEMAP program (Green et al., 2012a; Green et al., 2012b), to the south by the USGS Sarasota 30 x 60 minute quadrangle, mapped under the STATEMAP Program (Green, et al., 1997; Green, et al., 1998), and to the east by the USGS Bartow 30 x 60 minute quadrangle (Figure 1). The study area encompasses most of Old Tampa, Tampa, and Hillsborough bays, along with the Alafia, Little Manatee, and Manatee rivers, numerous creeks, and springs. Recharge to the Floridan aquifer system (FAS) occurs throughout the study area. The FAS is the primary source of water for springs and drinking water in the region.

One objective for this report is to provide basic geologic information for the accompanying OFMS 109. Information provided by this report and the plates in OFMS 109 is intended for a diverse audience of professionals in geology, hydrology, engineering, environmental and urban planning, and laypersons, all of whom have varying levels of geologic knowledge. The maps can help users identify and interpret geologic features which impact activities related to groundwater quality and quantity, as well as aid in locating mineral resources, land-use planning, and construction project design. Applied uses of the maps and data in this report include: 1) identifying potential new mineral resources, 2) characterizing zones of potential aquifer recharge and confinement, 3) aiding water-management decisions on groundwater usage, 4) providing information on aquifer vulnerability to pollution, 5) ecosystem, wetlands, and environmental characterization, and 6) recreation.

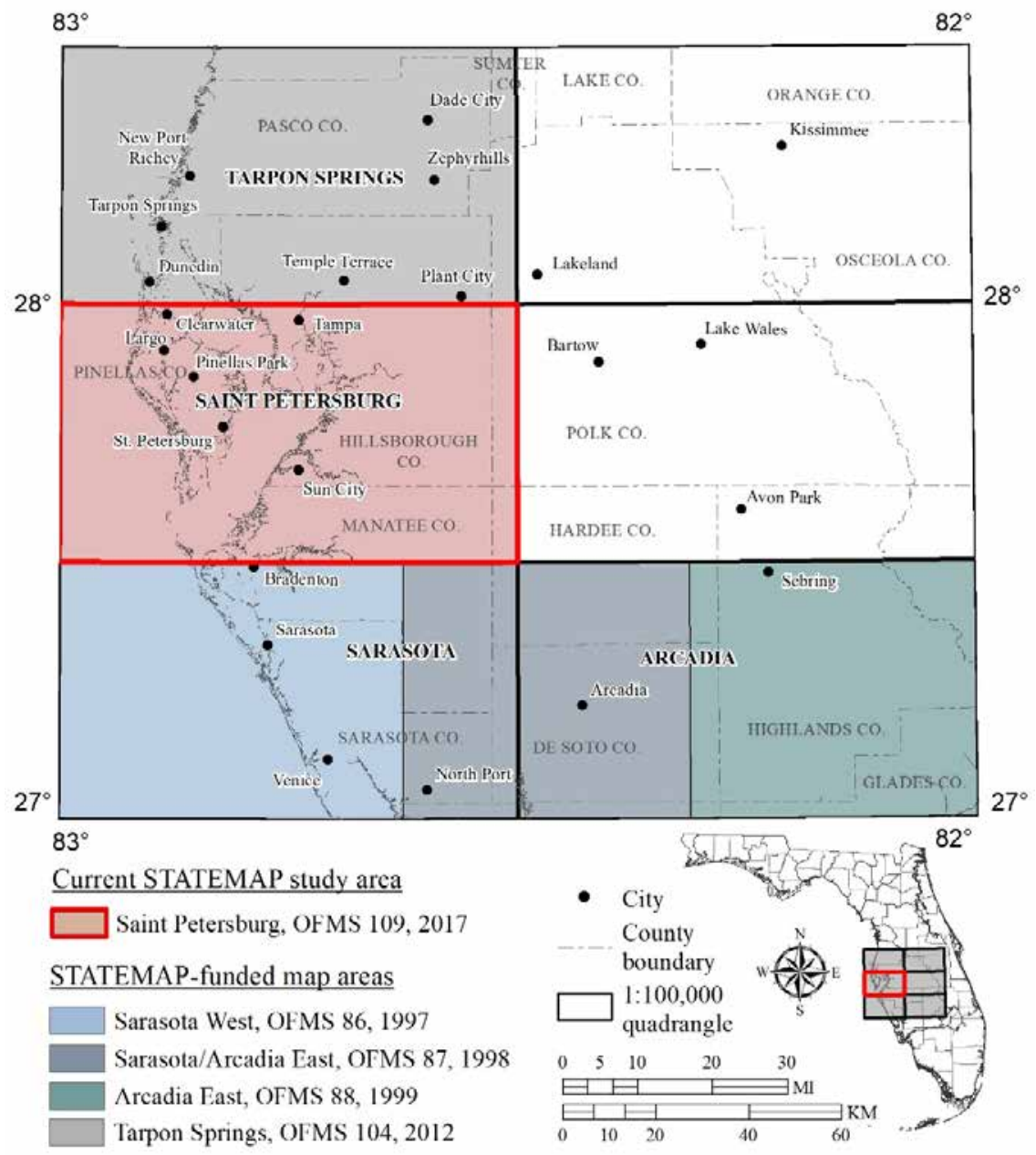

Figure 1. Nearby areas mapped under the FGS STATEMAP Program. 


\section{Methods}

Mapping efforts consisted of: 1) reviewing and compiling existing geologic literature and data, 2) mapping geologic units in the field at 1:24,000 scale using standard techniques, 3) analyses of existing core and cuttings samples from the FGS sample repository, 4) new core drilling, 5) collecting and describing outcrop samples, and 6) preparing a geologic map, geological crosssections and geomorphic map of the area. Field work, performed during the fall of 2016 through the summer of 2017, consisted of sampling and describing numerous outcrops, as well as samples from river and quarry exposures.

Thirty-nine new geologic samples were added to the FGS surface-sample archives (MSeries) and two cores (670 feet or 204.2 meters total) were drilled. Approximately 100 outcrops and exposures were also examined during this project. In addition to the new M-series samples collected, 50 historical M-series samples were examined. All data, including over 400 wells from the study area and surrounding quadrangles, were compiled and analyzed by the authors. Figure 2 shows the locations of FGS cores, cuttings, and M-series samples within the study area. The map and accompanying plates were developed in $\mathrm{ESRI}^{\circledR}$ ArcGIS $^{\circledR}$ ArcMap $^{\mathrm{TM}}$ 10.3.1 software for publication as part of OFMS 109.

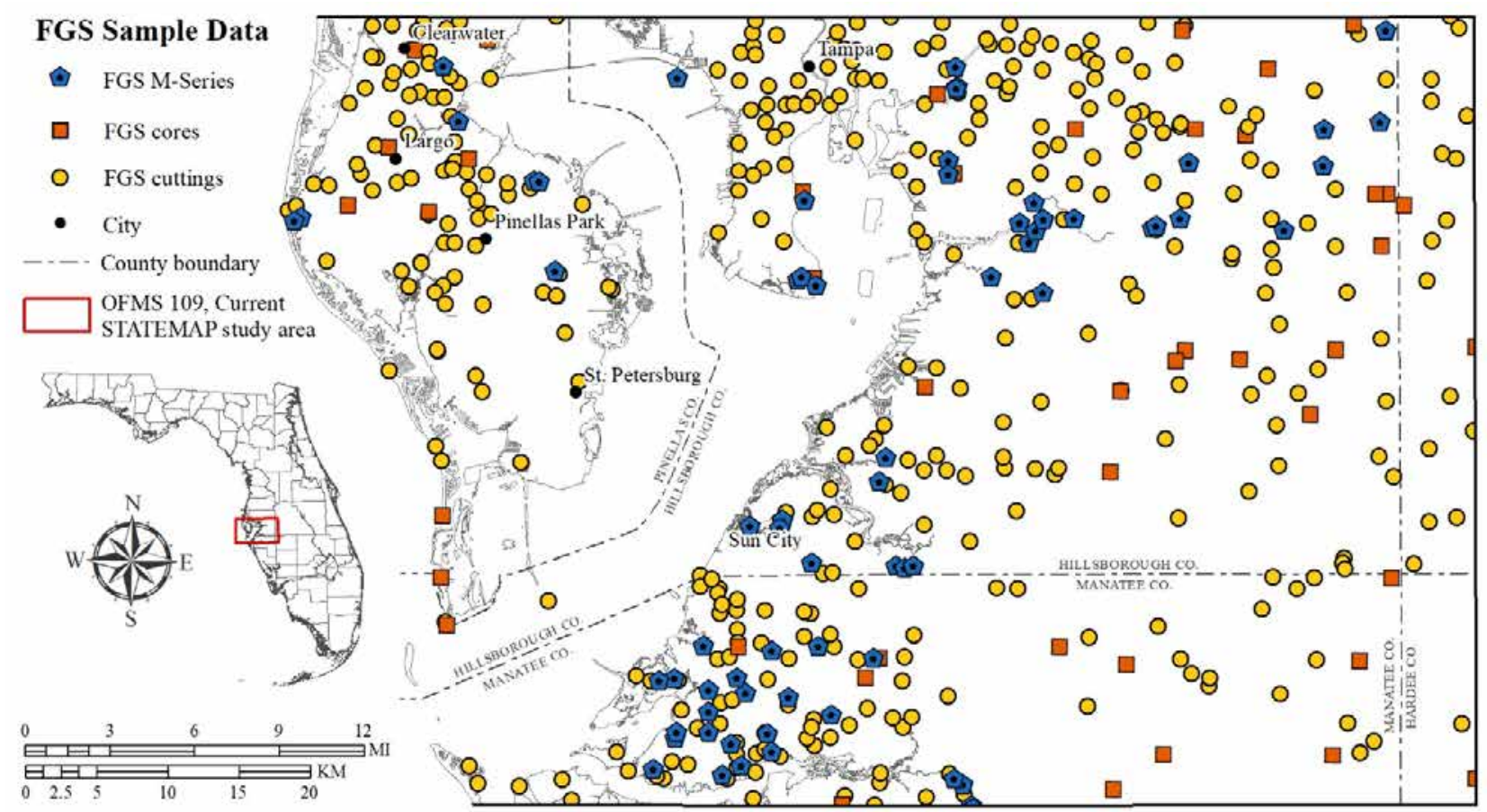

Figure 2. FGS cores, cuttings, and M-series samples used for models.

Top of unit models were created for several geologic units within the study area, using the borehole descriptions produced during the course of this study. In order to produce these interpolated surfaces, the tops of each unit were converted from depths below land surface to elevations referenced to mean sea level. This conversion was performed by taking the elevation value of the well point from the digital elevation model raster and subtracting the depth value. In cases where boreholes fell within the borders of the mined areas, where the original land surface has been disturbed (and elevation may have changed), the original documented elevation of the well at the time that it was drilled was used. 
Modeling was performed using ArcMap's Geostatistical Analyst extension. All surface models were created using the Simple Kriging method or the Empirical Baysian Kriging methods. Regardless of the kriging method used, substantial attention was devoted to manually tuning each model to ensure a good fit to the empirical semivariogram of each dataset. All of the units exhibited non-normal distributions and significant trends within the study area, and in order to correct for this, the data were adjusted using the normal score method and detrended using the first, second, or third polynomial detrend functions prior to modeling. Model parameters - primarily the kernel type, lag distance, and number of lags were manually adjusted for each unit to ensure goodness of fit of the model to the data and to produce models with a suitably low average standard error and an average error approaching zero.

After examining the borehole data for each unit, it was evident that the high amount of predictive error in these models was attributable to either low data density, a handful of local outliers in the borehole data, or both. Outliers are a common occurrence in Florida geologic data for a variety of reasons both human and natural, including: 1) Hawthorn Group units can be difficult to distinguish even for a trained professional geologist, and therefore some degree of uncertainty always exists in locating contacts, 2) many of the borehole samples are based on cuttings taken at intervals of 10 feet, which introduces uncertainty in the elevation of the contacts even when the contact is clearly evident, and 3) the presence of karst in limestone units can produce significantly different unit elevations in boreholes a short distance apart. In cases where the resultant surfaces indicated large errors, an iterative modelling process was used to reduce the average standard error of the interpolated surface, whereby the boreholes were cross validated with the first model in order to find boreholes that were the worst performing in terms of predictive accuracy. These boreholes - generally 5 or less for each unit - were then removed from the data and a new model was built out of the subset of boreholes.

After the top of unit models were completed, they were exported to floating point rasters whose cell size and borders were snapped to a hybrid digital elevation model. These interpolated surfaces were then subtracted from the elevation model to produce a raster showing overburden depth between each unit and land surface. The overburden rasters were then used to assist in drawing the final surficial geologic map for the study area.

Figure 3 is a boxplot of the ranges in elevations of mapped units, relative to mean sea level (MSL), based on core and cuttings data. The elevations were calculated by subtracting the unit's depth below ground level from the elevation of the land surface. Each unit's depth was retrieved from both core and cutting samples, while the land surface elevation was extracted from the DEM. The resulting values are the units' elevations relative to MSL. The crossbar within the box represents the median elevation value for each geologic unit. The upper and lower borders of each box correspond to the $25^{\text {th }}$ and $75^{\text {th }}$ percentiles, or the first and third quartiles, respectively; this area is also called the interquartile range and represents the middle $50 \%$ of the values in each group. The whiskers that extend from each boxplot reach no further than $150 \%$ of the interquartile range. Data that fall beyond the whiskers are considered outlier points and are represented by a dot. These plots were then used to determine which points should be considered for removal from the analyses and the models were re-run without the selected outliers.

Upon completion of the box plots and removal of problematic data points, an ordinary kriging method was used to generate a top of unit surface using the "stable" algorithm. Lag size was empirically calculated based on the total spatial extent of the combined datasets, and adjusted slightly to improve model performance. The error values for all data were examined after each 
iteration of the model, and any points with a standardized error greater than five or less than negative five were discarded in order to improve the final model performance.

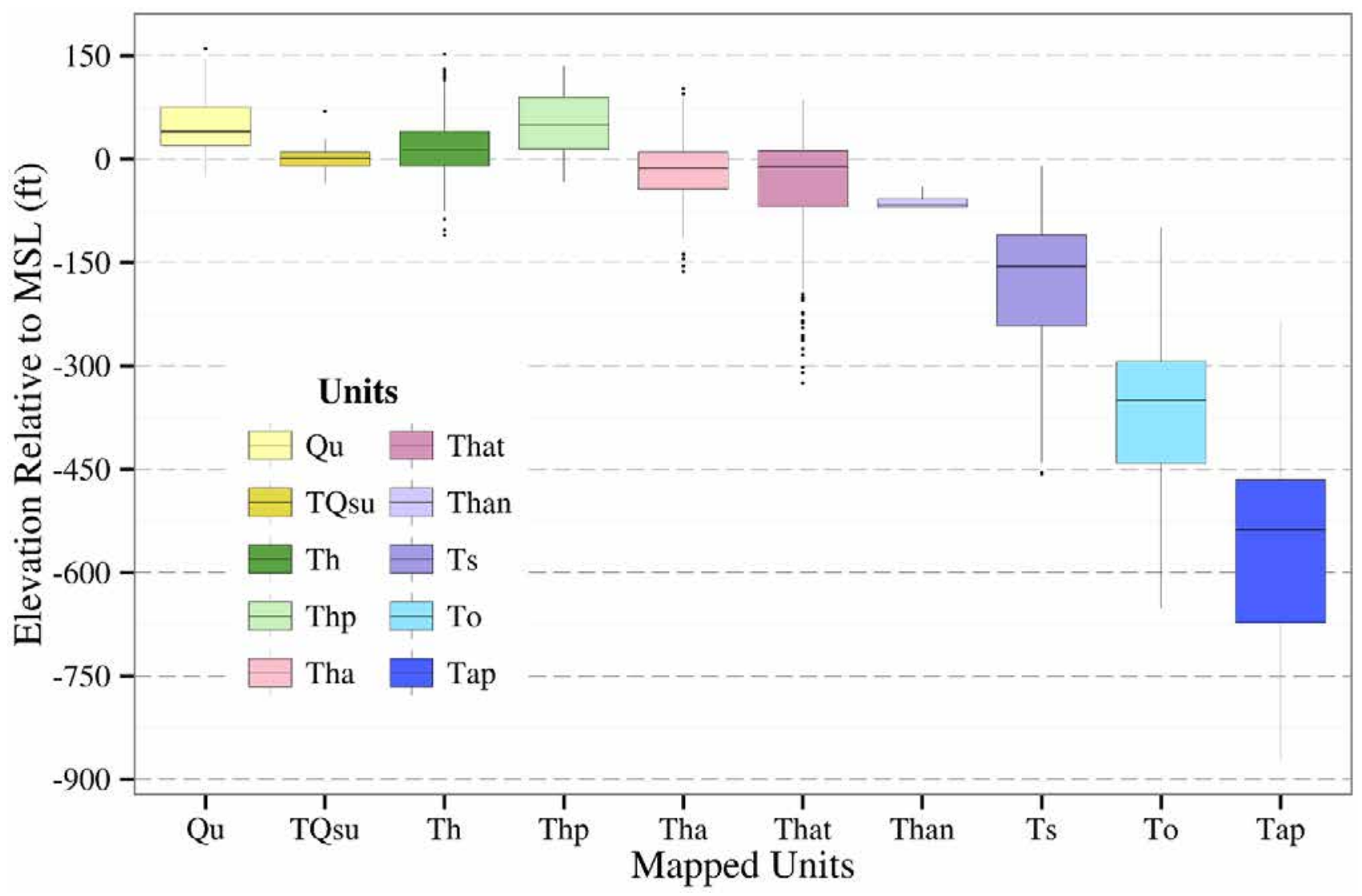

Figure 3. Boxplot of top of lithostratigraphic unit elevation ranges.

Much of the study area is blanketed by a veneer of undifferentiated Tertiary and Quaternary sediments and soils. For this reason, and in keeping with geologic mapping practices developed by Scott et al. (2001), the authors have adopted the policy of mapping the first named geologic unit within 20 feet (6.1 meters) of the surface. If undifferentiated Quaternary (Qu), or Holocene (Qh) sediments attain a thickness greater than 20 feet (6.1 meters), then they appear as the mapped unit. If these undifferentiated sediments are less than 20 feet (6.1 meters) thick, then the underlying lithostratigraphic unit appears on the map.

Parts of the region are heavily vegetated, and public access in parts of the mapped area is hindered by the presence of numerous wetlands, phosphate mines, farms, ranches and privatelyowned land. Additionally, much of the coastal area is heavily developed with subdivisions, many of which are gated communities. Fieldwork access was typically limited to public roads, Stateowned, and County-owned lands. Furthermore, much of the study area is impacted by current and historic mining of phosphate. As such, large sections of the mapped area were inaccessible. In these areas, the authors had to rely on historic data, cores, and cuttings. 


\section{Previous Work}

The current study builds on many previous geologic investigations in and around the present map area which were useful in preparing this report. Preliminary county geologic maps for Hardee (Scott and Campbell, 1993), Hillsborough (Campbell and Arthur, 1993), Manatee (Campbell, 1993a), Pinellas (Arthur and Campbell, 1993), and Polk (Campbell, 1993b) counties were previously published at a 1:126,720 scale by the FGS. However, each of these OFMS geologic maps were constructed in an average time-frame of two weeks utilizing selected in-house geologic data with little-to-no extra field work. Although these maps provided a starting point for the detailed geologic mapping undertaken for this project, significant refinement of prior geologic maps was possible as a result. A statewide geologic map (Scott et al., 2001) was published by the FGS in digital format and provided a framework for the current, more detailed mapping.

Scott (1988) published detailed descriptions, structure contour maps, and isopach maps for units of the Hawthorn Group. Arthur et al. (2008) provided unit descriptions, structure contour and isopach maps of all of the major lithostratigraphic units investigated in this study.

This study benefited from the work performed during geologic mapping of the USGS Tarpon Springs 30 x 60 minute quadrangle (Green et al., 2012a; Green et al., 2012b) and the USGS Sarasota and Arcadia quadrangles (Green et al., 1997, and Green et al., 1998). Some of the field relationships and stratigraphic problems were worked out during those projects. Data gathered during work on the Tarpon Springs, Sarasota, and Arcadia quadrangles proved invaluable to the completion of this project.

\section{GEOLOGIC SUMMARY}

The near surface geology of the USGS 30 x 60 minute Saint Petersburg quadrangle is composed of a complex mixture of Oligocene to Quaternary carbonate and siliciclastic sediments. A combination of factors, including fluvio-deltaic deposition, marine deposition, dissolution of underlying carbonates (karstification), erosion of sediments as a result of eustatic changes in sea level, and structural features have influenced the geology of the study area.

Tampa Bay displays aspects of drowned river valley morphology, particularly with the Hillsborough River and Hillsborough Bay. Yet, the present rivers flowing into the bay are underfit to the size of Tampa Bay. Work by Hine et al. (2009) indicates that karst basin complexes, each on the order of tens of kilometers in diameter with depths of 40-60 meters, exist as interpreted from regional seismic data. Deep-seated dissolution during the middle to late Miocene, suggested by deformation of the underlying late Oligocene to middle Miocene carbonates, caused stratigraphic collapse of the subbasins. Infill from the Miocene onward includes carbonates, followed by siliciclastic fluvio-deltaic sediments, in the Miocene and Pliocene, and mostly coastal sedimentary processes from Pleistocene to Recent (Duncan et al., 2003). Regionally, the infill has been from north to south, as apparent on cross-sections (OFMS 109, Plate 2, cross sections D-D', E-E', and F-F'). Missimer and Maliva (2017) provide detailed discussion regarding the southern Appalachian Mountains sediment source for the siliciclastics deposited in South Florida during the Miocene and Pliocene.

The oldest unit to crop out in the Saint Petersburg quadrangle is the late Oligocene to middle Miocene Arcadia Formation (Hawthorn Group). It crops out at various locations in the southern portion of the map area (OFMS 109, Plate 1). The Tampa Member of the Arcadia Formation crops out in northwestern Hillsborough County along the shores of Old Tampa Bay, Tampa Bay, Hillsborough Bay, and portions of the Alafia River (OFMS 109, Plate 1). The middle 
Miocene to lower Pliocene Peace River Formation (Hawthorn Group), which unconformably overlies the Arcadia Formation and the Tampa Member (Arcadia Formation), crops out in much of the eastern portion of the study area. Sediments of undifferentiated Oligocene to Pliocene Hawthorn Group and undifferentiated Tertiary/Quaternary shelly sediments, and undifferentiated Quaternary sediments overlie various units of the Hawthorn Group in the western portion of the map area (OFMS 109, Plates 1 and 2).

The first significant carbonate unit encountered in boreholes in the mapped area is the top of the Arcadia Formation (which includes the Tampa Member of the Arcadia Formation in some areas). This unit is unconformably underlain by the lower Oligocene Suwannee Limestone, which is unconformably underlain by the Eocene Ocala Limestone, throughout the study area. These latter two formations can both vary from wackestone to grainstone. Current authors and others (Brewster-Wingard et al., 1997) have noted that, lithologically, the contact between the Suwannee Limestone and the Ocala Limestone can be difficult to differentiate in cores and cuttings. At times there is a distinct contact between the two formations; however, this is not always the case.

Detailed description of the lithology of all units found in the study area start on page 15 of this publication. Along with lithologic criteria, several diagnostic foraminifera and echinoids aid in distinguishing the Suwannee Limestone from the Ocala Limestone. Furthermore, there are some similarities between benthic foraminifera assemblages of the Suwannee Limestone, and the Avon Park Formation (which unconformably underlies the Ocala Limestone) that help to distinguish these units from the Ocala Limestone. Both of the former units contain Fallotella spp. which is found infrequently at the base of the Ocala Limestone (personal communication, Jonathan Bryan), as well as Discorinopsis gunteri, which is not found in the Ocala Limestone. The occurrence of Nummulites spp. and Lepidocyclina spp. in the Ocala Limestone helps to distinguish it from the Suwannee Limestone and the Avon Park Formation in the study area.

The Saint Petersburg quadrangle encompasses portions of the Crystal River to St. Petersburg, Hillsborough, Tampa Bay, Alafia, Little Manatee, Manatee, and Peace River basins (Figure 4). Small portions of the Myakka River and Sarasota Bay basins occur along the southern edge of the study area (Hydrologic Unit Codes: Basins, 1993). There are numerous springs in these basins within the study area, including 26 springs in Hillsborough County and two springs in Pinellas County.

Many of these springs, which developed as karst features under lower water table conditions, have shown significant increases in pollutants in the last few decades, particularly nitrate (Phelps, 1994; Phelps, 2004; Jones et al., 1996; Scott et al., 2002; Upchurch et al., 2004; Copeland et al., 2009). Detailed geologic mapping of lithostratigraphic units in this area provides critical data needed for future assessments of the vulnerability of the aquifer systems and springs to contamination. Understanding the surficial geology of the map area is a key factor in developing management and protection plans, not only for the springs, but for the unconfined portions of the Floridan aquifer system.

Karst processes have extensively modified the topography of the region, and continue to actively shape it today. Karst topography is characterized by solutional features, subterranean drainage, and caves, all of which occur within the study area (Poucher and Copeland, 2006). Downward infiltration of slightly acidic rain and surface water through preferential pathways, such as joints, fractures, and bedding planes, combined with groundwater fluctuations, cause dissolution of the carbonate rocks (Waltham et al., 2005). 


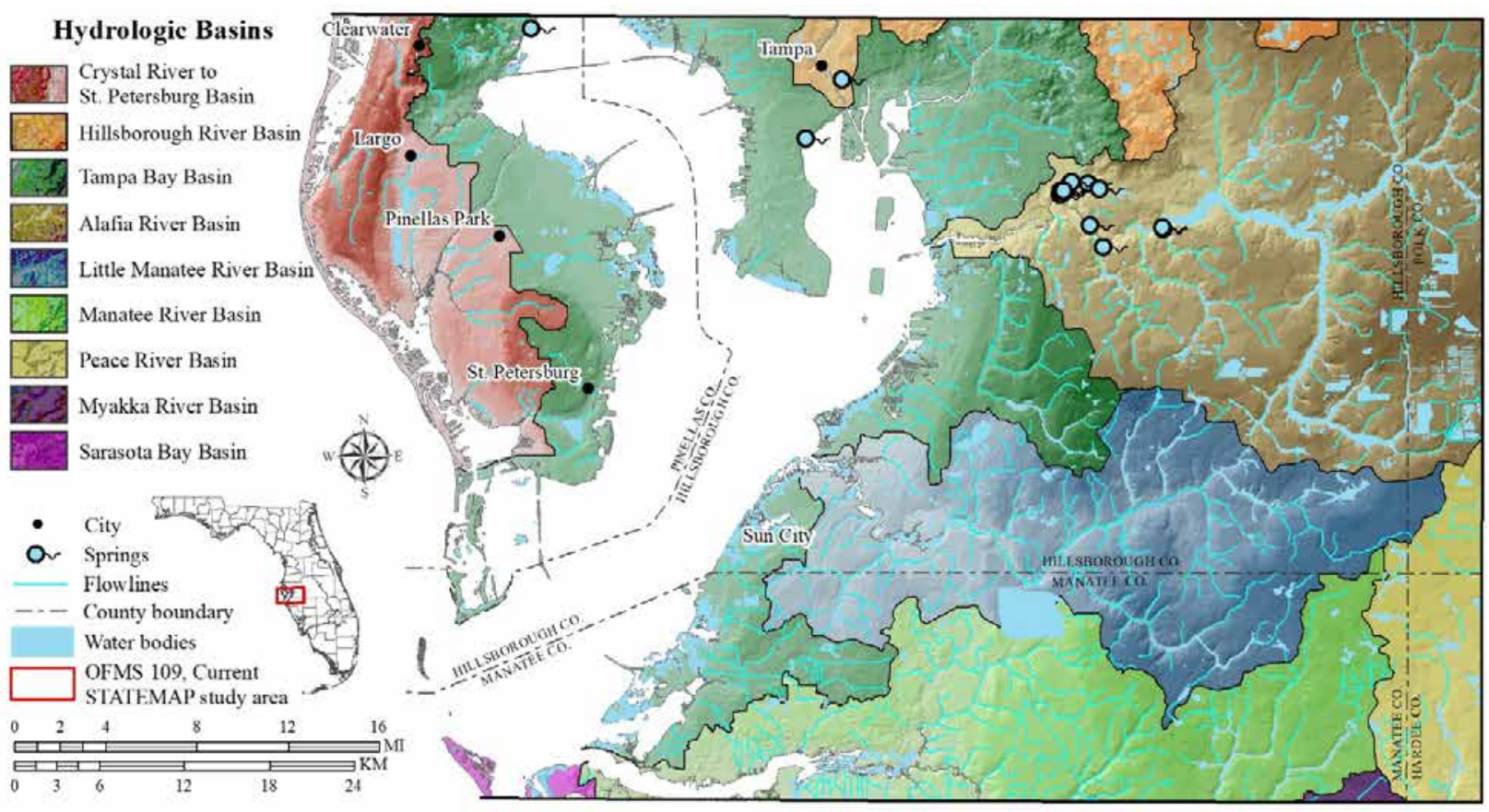

Figure 4. Location of selected river basins, springs, and other water bodies.

The most common karst landforms observed in the study area are sinkholes. Three types of sinkholes dominate the region: 1) solution-subsidence, 2) cover-subsidence, and 3) covercollapse. Solution-subsidence sinkholes occur where overburden is relatively thin. Downward percolating rain and surface water infiltrates into joints, fractures, and bedding planes slowly dissolving the carbonate rocks below generally forming a large, broad, shallow low-angle surface depression (Tihansky, 1999). Cover-subsidence sinkholes occur where overburden is relatively thick. The overburden sediments, which consist primarily of low cohesion sediments, ravel into joints, fractures, and cavities below via infiltrating rain and surface water, resulting in a relatively small, gently sloped surface depression (Waltham et al., 2005). Cover-collapse sinkholes occur where the overburden contains some amount of cohesive sediments, such as clay, that acts mechanically as a bridge overlying a cavity within the carbonate rocks below (Waltham et al., 2005). The overburden sediments abruptly collapse into the cavity when either the weight of the overburden sediments exceeds the bridging sediment's load-bearing capacity, or when the potentiometric surface of groundwater within the carbonate rocks drops below bridging sediments, no longer providing the necessary buoyancy to help support those bridging sediments (Waltham et al., 2005; Beck and Sinclair, 1986).

The variability of the karst observed within the study area is closely related to the thickness of overburden and the presence/absence of Hawthorn Group clays within the overburden mantling the region's carbonate rocks. Those clays are often the sediments that create a bridge over any cavities which have formed within the carbonates. Karst is more common at the surface in the northern part of the study area, particularly in northern Hillsborough County. In northwestern Hillsborough County, the Peace River Formation and undifferentiated Quaternary sediments overlie the limestones of the Tampa Member of the Arcadia Formation. Cover-subsidence sinkholes are more common in this region as are springs. This area is within the Land O' Lakes 
Karst Plain province (discussion of geomorphology begins on page 10). In northeastern Hillsborough County, thin undifferentiated sediments, along with Peace River Formation sediments, overlie the Tampa Member of the Arcadia Formation. This region is within the Hardee Upland province. Karst occurs in the northern extent of the Hardee Upland where carbonates are closer to the surface. Due to clays in the Peace River Formation, cover-collapse sinkholes occur more frequently. Most of the Hardee Upland has thick siliciclastic deposits overlying the carbonates which limit the surface expression of karst features. Both cover-subsidence and covercollapse sinkholes are possible throughout the northern part of the study area (Sinclair and Stewart, 1985).

Anthropogenic activities, combined with extreme weather and climatic conditions, can lead to accelerated sinkhole development. The Saint Petersburg quadrangle and surrounding area have experienced two such events in the last decade. In January 2010, freezing or near freezing conditions were experienced for record 11 consecutive days within the Plant City/Dover area, which has and abundance of strawberry farms. In order to protect their crops, farmers sprayed them with groundwater to create a protective rind of ice which insulated the crop from freezing temperatures (SWFWMD, 2010). During freezing conditions, farmers were allowed to pump additional amounts of groundwater beyond their normal permitted daily rate of consumption. During average seasonal weather conditions, farmers in the Plant City/Dover area were permitted to pump approximately 38 million gallons per day (MGD; SWFWMD, 2010). During freezing conditions, farmers in the Plant City/Dover area were permitted to pump up to approximately 942 MGD, a 2,479\% increase in pumping above normal rates (SWFWMD, 2010). Pumping at that increased rate caused water levels in the FAS to drop as much as 60 feet in and around the Plant City/Dover area (SWFWMD, 2010). As a result of that extreme drop, over 750 local wells went dry, and more than 150 sinkholes formed within the vicinity (SWFWMD, 2010).

In June 2012, Tropical Storm Debby dropped record amounts of rain on portions of the state of Florida and caused significant flooding (National Oceanic and Atmospheric Administration, 2012). In 2011, leading up to that storm event, Florida was experiencing drought conditions during which regional groundwater levels had been lowered due to the lack of rainfall and groundwater pumping. With such lowered regional groundwater levels, much of the region's overburden sediments no longer had the necessary buoyancy support from below. As such, when the rains associated with Tropical Storm Debby fell on the area, the additional weight from the rain water in the overburden sediments, and lubrication of sediments, caused the formation of numerous sinkholes around the state including this area.

\section{Structure}

Several structural features have affected the geology of the region (Figure 5). The Peninsular Arch, a structurally high area which affected deposition from the Cretaceous to the early Cenozoic, is the dominant subsurface feature of the Florida peninsula (Applin and Applin, 1944; Applin, 1951; Puri and Vernon, 1964; Williams et al., 1977; Schmidt, 1984; Miller, 1986; Scott, 1997). The axis of the Peninsular Arch, which lies to the north and east of the study area, extends from southeastern Georgia to the vicinity of Lake Okeechobee in southern Florida in a general northwest to southeast trend. The crest of the arch passes beneath Alachua County and is highest in Union and Baker counties north of the study area. The arch was a topographic high during most of the Cretaceous Period and had Upper Cretaceous sediments deposited upon it (Applin, 1951). It formed a relatively stable base for early Cenozoic carbonate deposition 
(Williams et al., 1977). The arch did not affect mid-Tertiary to Holocene sediment deposition (Williams et al., 1977; Scott, 1997).

The Ocala Platform is the most prominent feature affecting the near surface units within the map area. Hopkins (1920) originally named this feature the Ocala Uplift. Vernon (1951) described the Ocala Uplift as a gentle flexure developed in Tertiary sediments with a northwestsoutheast trending crest. Because there is continuing uncertainty about the origin of this feature, Scott (1988) used the term Ocala Platform, rather than Ocala Uplift, or Ocala Arch, since it does not have a structural connotation.

The current study area is on the southwestern flank of the Ocala Platform, which influenced late Tertiary sediment deposition. Miocene sediments of the Hawthorn Group are thought to have been deposited across the platform (Scott, 1981a; Scott, 1988; Scott, 1991a). Post-Miocene erosion has removed sediments of the Hawthorn Group from much of the crest of the Ocala Platform, exposing Eocene and Oligocene carbonates (Cooke, 1945; Espenshade and Spencer, 1963; Scott, 1981b). This is evident throughout the central portion of the map area where the Tampa Member of the Arcadia Formation (Hawthorn Group) is mapped (OFMS 109; Plate 1).

The South Florida Basin (Applin and Applin, 1965; Winston, 1971) is a stratigraphic basin which contributed to the southward thickening of Mesozoic and early Cenozoic lithostratigraphic units in the southern Florida peninsula. The reader is referred to Arthur, et al., (2008) for a more complete discussion of structural features in the area.

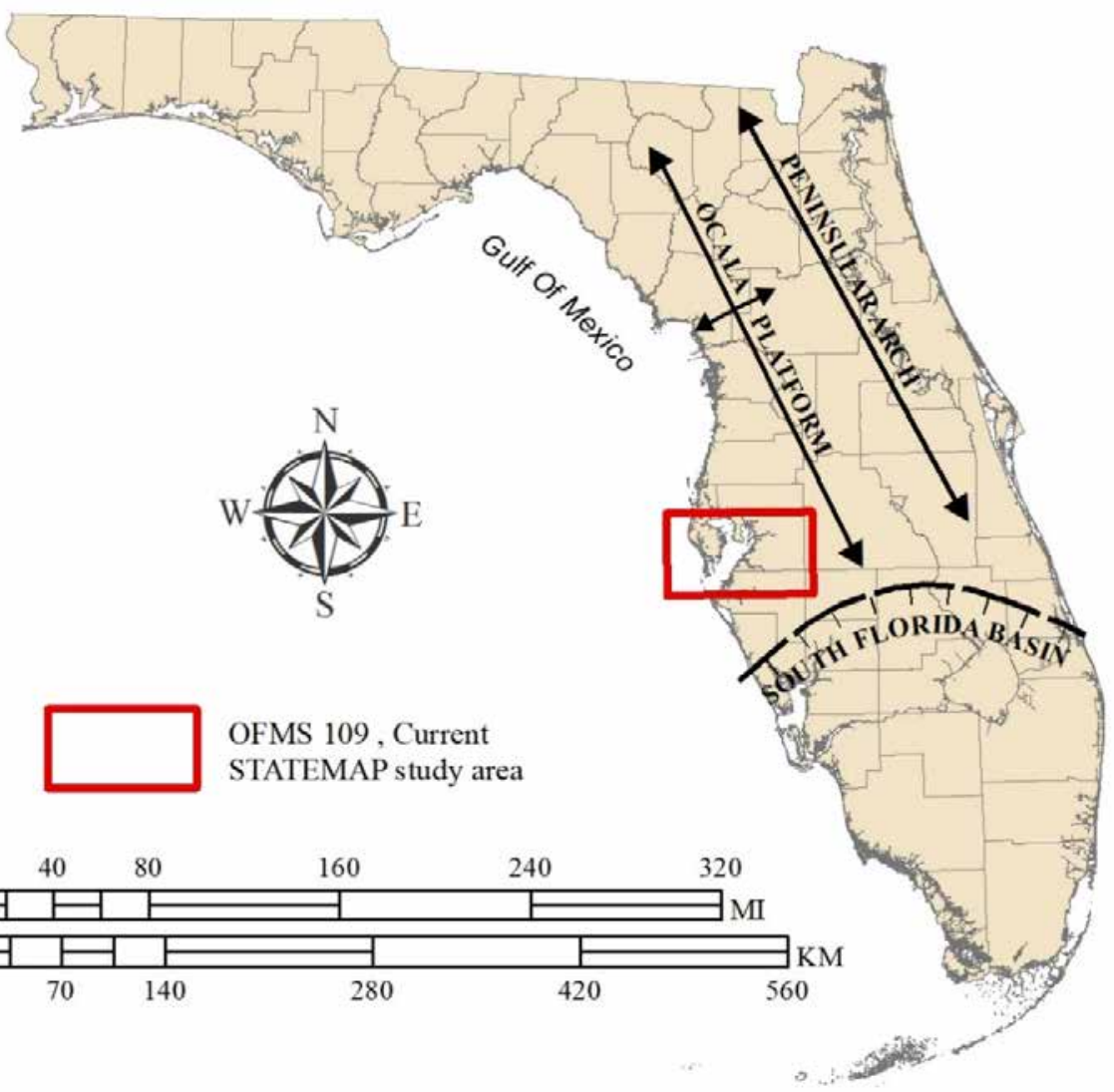

Figure 5. Principal subsurface structures of the Florida peninsula (modified from Arthur et al., 2008). 


\section{Geomorphology}

The Florida Geological Survey is in the process of producing a new statewide geomorphic map of Florida (Williams et al., in preparation). The new map will synthesize over a century of geomorphic writings and maps about Florida, along with the addition of new data and new interpretations of the geomorphology. The Geomorphology of the Florida Peninsula (White, 1970), in addition to significant work by retired FGS colleague, Thomas Scott, are central to the new statewide map. More recent data and technology, particularly the addition of significant coverage of LiDAR and new possibilities for digital geomorphological mapping that employ spatio-temporal and geocomputational approaches to data analysis, are allowing the FGS to revise nomenclature and refine boundaries for some units in Florida. In the section which follows, all geomorphology unit names and discussions are from Williams et al. (in preparation).

The new map will divide the geomorphology by regional units (districts) and sub-regional to local units (provinces; Figure 6). Districts are defined by regional groupings in which the geomorphology and near-surface geology are combined to form map polygons that are distinct from adjacent districts. Definition of the more localized provinces and their morphologies are important for the characterization of the districts.

Based on the work of Williams et al. (in preparation), the study area falls within two geomorphic districts: the Ocala Karst District and the Peace River District (OFMS 109; Plate 3, Figure 3). The Ocala Karst District has one province (The Land O’Lakes) present in the mapped area (OFMS 109; Plate 3, Figure 4). In the study area, the Peace River District is further subdivided into three provinces: the Hardee Upland, the Peninsula Coastal Lowlands, and the Pinellas Ridge.

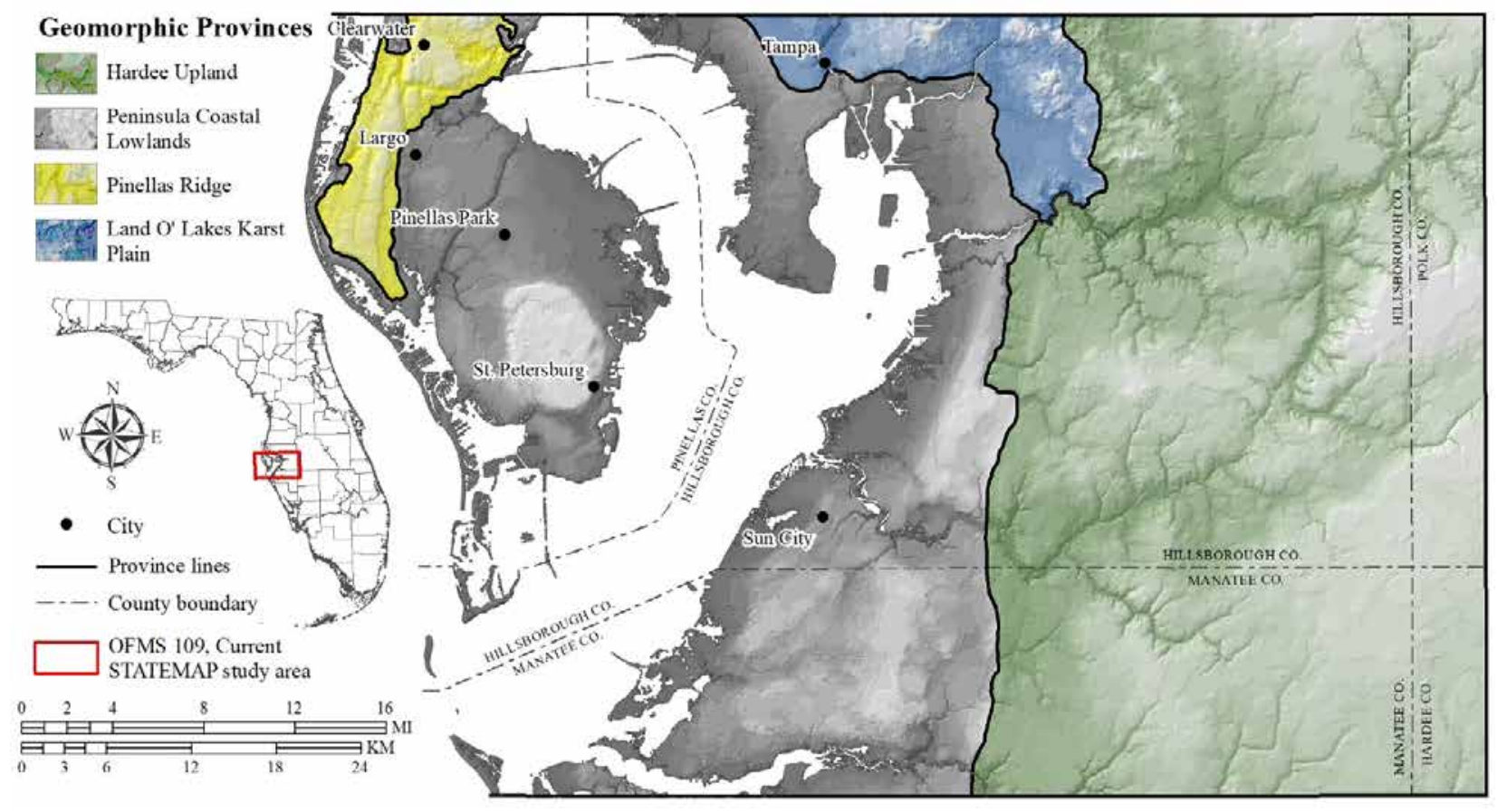

Figure 6. Geomorphic provinces. 


\section{Ocala Karst District}

The Ocala Karst District encompasses a broad area of White's (1970) Gulf Coastal Lowlands and Coastal Swamps from Franklin County in the panhandle to Hillsborough and Pinellas counties in west-central peninsular Florida (OFMS 109; Plate 3, Figure 3). Carbonate sediments ranging in in age from middle Eocene through early Miocene lie at or near the land surface (Scott et al., 2001; Evans et al., 2004; Green et al., 2005; Green et al., 2006; Green et al., 2007a; Green et al., 2007b; Green et al., 2008a; Green et al., 2008b; Green et al., 2009a; Green et al., 2009b; Green et al., 2010; Williams et al., 2010; Green et al., 2011; Williams et al., 2011; Williams et al., 2012; Green et al., 2012a; Green et al., 2012b; Green et al., 2013a; Green et al., 2013b; Green et al., 2015a; Green et al., 2015b). Along the Gulf of Mexico coastline there are the karst dominated terrains of the Woodville Karst Plain, Perry Karst, Chiefland Karst Plain, Gulf Hammock, Crystal River Karst Plain, and Land O’ Lakes Karst Plain. Elevations within the district range from sea level along the Gulf of Mexico to just over 300 feet (91 meters) above MSL on Brooksville Ridge. The topography over much of the district is gently rolling with only minor relief. However, on the Brooksville Ridge, the terrain looks more like that of the Lakes District and relief may exceed 200 feet (61 meters). Dissolution of carbonates has created distinct landforms that characterize the Ocala Karst District, including caves, caverns, numerous springs, sinkholes, siphons, swallets (sinking streams), and resurgences. The southern terminus of the district occurs where the impermeable Hawthorn Group sediments retard the development of karst features in the Peace River District and streams and rivers become more common. The entire district has siliciclastic cover of varying thickness ranging from a few feet (1 meter) of sand and clay, to as much as 200 feet (61 meters) of sediment overlying carbonate rocks.

The Ocala Karst District is dominated by solution sinkholes, and shallow, broad, bowlshaped depressions, producing a gently rolling topography. This type of dissolution occurs in areas where there is a thin, permeable, siliciclastic cover allowing downward percolating groundwater to dissolve the limestone surface. These sinkholes develop slowly. Areas of the Ocala Karst District where there is a thicker cover of permeable siliciclastic sediments are characterized by cover-subsidence sinks. These areas have few shallow sinks formed by the downward movement of the siliciclastic cover to fill voids created by the dissolution of carbonate sediments. Coversubsidence sinkholes develop slowly in response to the dissolution. Cover-collapse sinkholes form in those areas where the siliciclastic sediments overlying the limestone are cohesive. Dissolution of the carbonate sediments forms voids into which the overlying sediments collapse. This type of sinkhole forms abruptly. The thickness of sediments covering the carbonates increases to the north, south, and east in the province. As the sediment thickness increases, the type of sinkholes and their abundance changes, grading from solution sinks to cover-collapse sinks. Rock collapse sinks occur, but are uncommon. The maturity of the karst varies across the district, and regional geomorphic terrains are recognized within the Ocala Karst District based upon elevation, abundance, and type of karst features, drainage, geology, and topographic relief. In general, toward the Gulf of Mexico coast, the karst is more mature and has less relief due to more extensive dissolution and erosion of the overlying siliciclastics. Planation by transgressing seas also influenced the geomorphology near the Gulf Coast. The Ocala Karst District developed on the crest of the Ocala Platform. 


\section{Land O’ Lakes Karst Plain}

The Land O’ Lakes Karst Plain occurs from southwestern Hernando County southward into northern Pinellas and Hillsborough counties. It lies west of the southern end of Brooksville Ridge and Green Swamp, and north of the Pinellas Ridge, Peninsula Coastal Lowlands, and Hardee Upland provinces. Elevations in the Land O' Lakes Karst Plain range from sea level to 140 feet (42.7 meters) above MSL, with most less than 80 feet (24.4 meters) above MSL. Highest elevations are in dunes at the northern end of the plain and in the regions adjacent to Brooksville Ridge. The occurrence of karst features varies from abundant and closely spaced to scattered. Sand dunes are present in several areas of the karst plain, particularly in the northern part of the Land O' Lakes Karst Plain in southwestern Hernando County and northwestern Pasco County. The terrain, which varies from poorly drained to well-drained, includes several coastal rivers, such as the Pithlachascotee, Anclote, and Hillsborough rivers. Much of the Hillsborough River valley is in the southeastern extent of the Land O' Lakes Karst Plain. The province also contains many springs.

The northern half of the Land O' Lakes Karst Plain is underlain by the lower Oligocene Suwannee Limestone or by the upper Eocene Ocala Limestone, where the Suwannee Limestone is missing through marine and karst erosion west of the Brooksville Ridge. The upper Oligocene to lower Miocene Tampa Member of the Arcadia Formation (Hawthorn Group) underlies the southern portion of the karst plain. Clays and sands of Miocene undifferentiated Hawthorn Group overlie the carbonate sediments in much of the area. Quaternary siliciclastic sediments, both undifferentiated $(\mathrm{Qu})$ and Beach Ridge and Dune (Qbd), cover much of the karst plain (Scott et al., 2001; Green et al., 2011; Williams et al., 2011; Williams et al., 2012; Green et al., 2012a; Green et al., 2012b).

\section{Peace River District}

The Peace River District, referred to as the Sarasota River District in earlier FGS publications, covers much of west-central peninsular Florida extending from Hillsborough and Pinellas counties, southward to the Caloosahatchee Valley in Lee and Glades counties. The district is characterized by the occurrence of numerous rivers and streams which are more common than in any other geomorphic district in the state, except possibly the Southern Pine Hills in the westernmost panhandle of Florida (OFMS 109; Plate 3, Figure 3). The rivers in the Peace River District include the Alafia, Little Manatee, Manatee, Myakka, Peace, and their tributaries. The Peace River District lies south of the Ocala Karst District, west of the Lakes District and northwest of the Everglades District (OFMS 109; Plate 3, Figure 3). Low permeability siliciclastic sediments of the Hawthorn Group underlie the Peace River District allowing the development of numerous rivers and streams (Scott et al., 2001; Green et al., 2012a; Green et al., 2012b; Green et al., 2105a; Green et al., 2015b).

The Ocala Karst District merges with the Peace River District where the Hawthorn Group sediments retard the development of karst features, which are common in the Ocala Karst District. The transition from the Peace River District to the Lakes District occurs where the low permeability sediments of the Hawthorn Group either become more permeable due to facies changes, or where Hawthorn Group sediments are eroded and no longer retard the development of karst features. The separation of the Peace River District from the Everglades District is defined where the surface-water flow pattern becomes westerly in the Caloosahatchee Valley. The landscape of the Peace River District is relatively flat, with limited relief outside of areas incised by local rivers and hills in the eastern part of the district in the Hardee Upland. Elevations range 
from sea level along the coastline, to more than 190 feet (57.9 meters) above MSL in the hills among the headwaters of the Alafia River. The Peace River District includes the Hardee Upland, Peninsula Coastal Lowlands, and Pinellas Ridge provinces (OFMS 109; Plate 3, Figure 4).

\section{Hardee Upland}

The Hardee Upland is a new province name that merges the areas of White (1970) which included his Polk Upland and DeSoto Plain. The Hardee Upland is a broad, sloped plain, but hydrologically an upland, with elevations from about 10 feet (3 meters) in the incised river valleys to over 190 feet (57.9 meters) above MSL. Elevations adjacent to the incised river valleys are approximately 60 feet (18.3 meters) above MSL. Elevations in the province rise moderately from west to east away from the Gulf of Mexico as opposed to the relatively slow rise from south to north. The Hardee Upland includes the headwaters and most of the tributaries of the Alafia, Little Manatee, Manatee, and Myakka rivers in the Peace River District. The central portion of the province is relatively flat. Much of the northern part of the Hardee Upland has been terraformed due to phosphate mining throughout the $20^{\text {th }}$ and into the $21^{\text {st }}$ century. Greatest relief occurs along numerous stream and river valleys that are incised into the underlying upper Oligocene-lower Pliocene Hawthorn Group and undifferentiated Quaternary siliciclastic sediments (Scott et al., 2001; Green et al., 2012; Green et al., 2015a; Green et al., 2015b). Very few karst features are recognized on the Hardee Upland.

The underlying geology and the observed landforms of the Hardee Upland are all similar. The former break by White (1970) between Polk Upland and DeSoto Plain was an ill-defined scarp that has been incised by the Peace River and its tributaries. It is generally at about 90 feet (27.4 meters) above MSL. While there is a change in elevation between northeastern and southern Hardee Upland, it is not distinct when travelling across the terrain due to the extended slope of the topography. Most of what White (1970) defined as DeSoto Plain is less than 100 feet (30.5 meters) above MSL, which includes the southern part of the Hardee Upland. The western portion of Hardee Upland has been more deeply incised by rivers due to the more rapid change in elevation from Tampa Bay in the Peninsula Coastal Lowlands to the west. Elevations in this region are similar to southern Hardee Upland. Elevations in northeastern Hardee Upland (former eastern Polk Upland) are greater than 100 feet (30.5 meters) above MSL. The lower Oligocene Suwannee Limestone underlies the extent of the Hardee Upland (Arthur et al., 2008). The upper Oligocene-lower Pliocene Hawthorn Group, consisting of phosphatic sand, clay, and carbonate, overlies the Suwannee Limestone. Sand and clayey sand of the weathered Hawthorn Group and undifferentiated Quaternary siliciclastic sediments overlie the Hawthorn Group (Scott et al., 2001; Green et al., 2012; Green et al., 2015a; Green et al., 2015b).

\section{Peninsula Coastal Lowlands}

The Peninsula Coastal Lowlands province forms the western portion of the Peace River District, adjacent to the Gulf of Mexico, from the Anclote Keys in the north to Sanibel Island in the south. It nearly surrounds the Pinellas Ridge in Pinellas County. It occurs in the region west and south of the Hardee Upland. Elevations in the Peninsula Coastal Lowlands vary from sea level to around 60 feet (18.3 meters) above MSL near the border of the Hardee Upland. The coastal areas are more impacted by erosion from recent Pleistocene sea level fluctuations than the relative highland areas to the east in the Hardee Upland. The boundary between the Peninsula Coastal Lowlands and the Hardee Upland, particularly in Manatee and Hillsborough counties, is at times 
arbitrary due to the fact that no single paleo-shoreline feature can be used for the entire boundary. The upland has been incised by the regional rivers, and much of the terrain from the Alafia River south to the Myakka River has higher elevation than the regions on the north and west sides of Tampa Bay. Even the area from the Myakka River to the boundary with Caloosahatchee Valley gently slopes away from the Gulf of Mexico, with lowlands more like western Tampa Bay being limited to areas adjacent to and west of Charlotte Harbor. The greatest variability in elevations in the Peninsula Coastal Lowlands is in the river valleys, which drain to the west and south in the Peace River District. Most of the province is underlain by upper Oligocene-lower Pliocene Hawthorn Group units and Pliocene-Pleistocene shelly sediments.

The uppermost sediments are the undifferentiated Quaternary deposits and Holocene sands and finer materials in estuaries and on the barrier islands of the Gulf of Mexico coastline (Scott et al., 2001; Green et al., 2012a; Green et al., 2012b). One feature of note is the hill in southern Pinellas County on which the city of St. Petersburg is located. Regarding elevation, and possible dissection, it would at first appear that it might be a detached portion of the Pinellas Ridge. Further examination of the regional geology reveals that this area is underlain by undifferentiated Tertiary/Quaternary shelly units which are more like the geology underlying the Peninsula Coastal Lowlands to the east of Tampa Bay in Hillsborough County. Therefore, this hill in southern Pinellas County is retained in the Peninsula Coastal Lowlands.

\section{Pinellas Ridge}

The Pinellas Ridge occurs in Pinellas County. It is bound on the north by the Land O' Lakes Karst Plain, and on the west, south, and east by the Peninsula Coastal Lowlands which broaden toward the south and east. The Pinellas Ridge consists of Miocene undifferentiated Hawthorn Group and undifferentiated Quaternary sediments that remain as a relative highland in Pinellas County (Scott et al., 2001; Green et al., 2012a; Green et al., 2012b). Elevations within the province range from sea level to over 105 feet (32 meters) above MSL. The ridge is well drained. The northern portion of the Pinellas Ridge, adjacent to the Land $O$ ' Lakes Karst Plain and just southwest of Lake Tarpon, contains a few small karst depressions. There are numerous sinkholes apparent on the topographic maps, LiDAR elevation models, and aerial photographs, but the karst is not as extensive and the geology is dissimilar enough that is not merged with the Land O' Lakes Karst Plain.

\section{LITHOSTRATIGRAPHIC UNITS}

\section{Tertiary System}

\section{Eocene Series}

\section{Avon Park Formation}

The middle Eocene Avon Park Formation (Tap), first named by Applin and Applin (1944), is entirely a subsurface unit within the USGS Saint Petersburg 30 x 60 minute quadrangle. It was encountered in many of the wells utilized for this study and efforts were made to include it in the geologic cross sections where suitable well coverages existed (see OFMS 109, Plate 2). In some instances, geologic cross-sections do not depict the Avon Park Formation due to graphical constraints (OFMS 109, Plate 2). 
The lithology of the Avon Park Formation can vary between limestone and dolostone. The limestones are cream to light brown to tan, poorly to well-indurated, variably fossiliferous grainstone and wackestone, with rare mudstone. They are often interbedded with tan to brown, very poorly to well-indurated, very fine to medium crystalline, fossiliferous (molds and casts), vuggy dolostones. Minor clay beds and organic-rich laminations may occur, especially at or near the top of the unit. Although not common, sedimentary structures include cross-beds and burrows. The burrows generally occur in the uppermost thinly bedded up-dip part of the formation (e.g., where the unit crops out in Citrus and Levy counties; Green et al., 2010; Williams et al., 2012). Accessory minerals include chert, pyrite, celestine, gypsum, and quartz (some as doublyterminated euhedral crystals "floating" in vugs).

Fossils present in the unit include mollusks, foraminifera (Spirolina sp., Lituonella floridana, and Cushmania [Dictyoconus] americana), echinoids (Neolaganum [Peronella] dalli), algae, and carbonized plant remains. Porosity in the Avon Park Formation is generally intergranular in the limestone section. Fracture porosity occurs in the more densely recrystallized dolostone, and intercrystalline porosity is characteristic of sucrosic textures. Pinpoint vugs and fossil molds are present to a lesser extent.

Distinction between the middle Eocene Avon Park Formation and the unconformably overlying unit, the upper Eocene Ocala Limestone, can at times be difficult in the study area. Dolomitization of the Avon Park Formation and common recrystallization of the lowermost Ocala Limestone has significantly altered the original rock lithology and fabric. Fossil indicators are only somewhat helpful because the latest deposits of the Avon Park Formation and the earliest deposits of the Ocala Limestone are both bank assemblages, consistent with deposition in a shallow-water limestone bank or plateau, not unlike the present-day Bahama Banks (Bryan, 2004). This is especially true in the southwestern portion of the study area, where the Avon Park Formation is deepest. In this area, the transition from the Ocala Limestone to the Avon Park Formation is typically, though not always, marked by a transition from a yellowish-gray grainstone, often containing Lepidocyclina ocalana and Nummulites ocalanus, to an orangish-brown, sucrosic dolostone. Approaching the northeast portion of the study area, the transition is characterized by a subtle textural change in the limestone and a change in fossil fauna where common Ocala Limestone benthic foraminifera give way to Fallotella sp. and Cushmania [Dictyoconus] americana.

The top of the Avon Park Formation ranges from approximately 390 feet (118.9 meters) below MSL in W-10577 (OFMS 109; Plate 2, cross-section A-A') to approximately 688 feet (209.7 meters) below MSL in W-16181 (OFMS 109; Plate 2, cross-section A-A'). Due to limited coverage of deeper wells, the total thickness of the Avon Park Formation was not investigated in this study. The Avon Park Formation forms part of the Floridan aquifer system (FAS; Southeastern Geological Society Ad Hoc Committee on Florida Hydrostratigraphic Unit Definition, 1986).

\section{Ocala Limestone}

The upper Eocene Ocala Limestone (To), first described by Dall and Harris (1892), is a biogenic marine limestone comprised largely of foraminifera, mollusks, echinoids, and bryozoans. The Ocala Limestone, which sits unconformably on the Avon Park Formation, is recrystallized to varying degrees within the study area.

Based on lithologic differences, the Ocala Limestone can be informally subdivided into an upper and lower unit (Scott, 1991b). This subdivision, while often apparent in cores and quarries, is not readily apparent in cuttings. As a consequence of this, the geologic cross-sections do not 
depict the upper and lower Ocala Limestone. The upper unit is typically a white to cream, fine- to coarse-grained, poorly to well-indurated, moderately to well-sorted, very fossiliferous limestone (wackestone, packstone, and grainstone). Fossils commonly include foraminifera (Lepidocyclina ocalana and Sphaerogypsina globulus), bryozoans, mollusks, and a rich diversity of echinoids. The lower unit is typically a white to cream, fine- to medium-grained, poorly to moderately indurated, moderately to well-sorted limestone (grainstone to packstone). Fossils include foraminifera (Amphistegina pinarensis, Nummulites [Camerina] vanderstoki, and Nummulites [Operculinoides] ocalanus), bryozoans, algae, mollusks, echinoids, and crustaceans.

The Ocala Limestone occurs throughout the study area (OFMS 109, Plate 2). The top of the Ocala Limestone ranges from 230 feet (70.1 meters) below MSL in W-10577, (OFMS 109; Plate 2, cross-section A-A' and F-F') to 635 feet (193.5 meters) below MSL in W-19338 (OFMS 109; Plate 2, cross-section E-E'). Very few of the wells utilized for geologic cross-sections penetrate the entire thickness of the Ocala Limestone. In these wells, the thickness of the Ocala Limestone ranges from 280 feet (85.3 meters) in W-9241 (OFMS 109; Plate 2, cross-section B-B' and F-F') to 95 feet (29.0 meters) in W-15379 (OFMS 109; Plate 2, cross-section A-A').

The Ocala Limestone is generally thickest in the southern portion of the study area off the nose of the Ocala Platform. It exceeds 250 feet (76.2 meters) in these areas (Arthur et al., 2008). The Ocala Limestone forms part of the FAS (Southeastern Geological Society Ad Hoc Committee on Florida Hydrostratigraphic Unit Definition, 1986).

\section{Oligocene Series}

\section{Suwannee Limestone}

The lower Oligocene Suwannee Limestone (Ts), named by Cooke and Mansfield (1936), consists of limestone (grainstone and packstone) in the study area. The unit is typically gray, tan, and yellowish gray, moderately to very well-indurated, finely to coarsely crystalline, with limited occurrences of fossiliferous beds. Chert is occasionally present in the unit in minor amounts. Porosity types include intergranular and moldic. Sedimentary features include bioturbation and cross-bedding (Budd, 2002). Fossils present in the unit include mollusks, corals, echinoids (including the index fossil Rhyncholampas gouldii), as well as abundant miliolids, and other benthic foraminifera such as Discorinopsis gunteri, Fallotella [Dictyoconus] cookei, and Fallotella [Coskinolina] floridana.

The Suwannee Limestone unconformably overlies the Ocala Limestone throughout the study area. The Suwannee Limestone may be conformably overlain by the Tampa Member of the Arcadia Formation (Hawthorn Group) in parts of Hillsborough and Pinellas counties and the Nocatee Member of the Arcadia Formation in the eastern part of the mapped area (Arthur et al., 2008). In these areas, the Suwannee Limestone and Tampa Member of the Arcadia Formation may be difficult to differentiate due to the presence of trace amounts (typically less than three percent) of fine quartz sand in the upper Suwannee Limestone and lower Tampa Member of the Arcadia Formation, leading geologists familiar with the region into using the term "SuwaTampaHaw" (Tom Scott, personal communication, 2004). In these instances, the formation break is based on the presence of phosphate, general increase in quartz sand size in the Tampa Member of the Arcadia Formation, and a commonly occurring subtle shift from a wackestone to a packstone in the Suwannee Limestone.

In the subsurface, the Suwannee Limestone and Ocala Limestone can be difficult to distinguish in the study area because both units may be dominated by packstones and often contain 
no diagnostic fossils. Brewster-Wingard et al. (1997) studied these units further south in the Florida peninsula and state: “...the delineation of the formational boundary [between the Ocala Limestone and the Suwannee Limestone] is often difficult, and foraminifera frequently provide the most reliable means for identifying the units." The present authors agree with this statement for the current map area.

The Suwannee Limestone is entirely a subsurface unit in the mapped area (OFMS 109, Plate 2). The top of the Suwannee Limestone ranges from approximately 75 feet (22.9 meters) below MSL in W-11541 (OFMS 109; Plate 2, cross-section A-A' and E-E') to 385 feet (117.3 meters) below MSL in W-16740 (OFMS 109; Plate 2, cross-sections C-C'). The thickness of the Suwannee Limestone ranges from 310 feet (94.5 meters) in W-1699 (OFMS 109; Plate 2, crosssection A-A') and W-802 (OFMS 109; Plate 2, cross-section E-E') to 130 feet (39.6 meters) in W10577 (OFMS 109; Plate 2, cross-section A-A' and F-F') and W-9241 (OFMS 109; Plate 2, crosssection B-B' and F-F'). The Suwannee Limestone makes up part of the FAS (Southeastern Geological Society Ad Hoc Committee on Florida Hydrostratigraphic Unit Definition, 1986).

\section{Oligocene-Pliocene Series}

\section{Hawthorn Group}

Sediments of the upper Oligocene to Pliocene Hawthorn Group are thought to have been deposited over the Ocala Platform throughout the study area, but post-Pliocene erosion and karstification have removed sediments from the crest of the Ocala Platform, exposing Oligocene carbonates in portions of the map area (Cooke, 1945; Espenshade and Spencer, 1963; Scott, 1981b). Hawthorn Group sediments within the study area consist of phosphatic siliciclastics (sands, silts and clay) and carbonates. Fossils in the Hawthorn Group are sparse but may include vertebrate remains, corals, and mollusks. Benthic foraminifera characteristic of the Hawthorn Group include Archaias spp. and Sorites sp. Williams et al. (1977) report that the most commonly found fossils are oysters and coral heads.

Within the mapped area, the Hawthorn Group is composed of sediments from the Arcadia Formation (including the Tampa and Nocatee members), the Peace River Formation (including the Bone Valley Member), and undifferentiated Hawthorn Group (Th). The sediments of the Arcadia Formation lie unconformably over the Suwannee Limestone. The various Hawthorn Group sediments are, at times, unconformably overlain by the undifferentiated Tertiary-Quaternary shelly sediments and/or undifferentiated Quaternary sediments.

Arcadia Formation

The upper Oligocene to middle Miocene (Brewster-Wingard et al., 1997) Arcadia Formation (Tha) is a yellowish gray to white, variably sandy (quartz and phosphorite) carbonate, intercalated with beds of siliciclastic-dominant sediments. Although limestone is present, dolostones are most common, ranging in grain size from microcrystalline to medium, with the coarser material being sucrosic. Minor clay and chert beds (some composed of silicified clay) also occur (Upchurch et al., 1982; Scott, 1988). Porosity types include intergranular and moldic. In places, the Arcadia Formation can be further subdivided into the Tampa Member and Nocatee Member. See below for further discussion of these units.

Undifferentiated Arcadia Formation sediments range from approximately 80 feet (24.4 meters) above MSL (OFMS 109; Plate 2, cross-section F-F', W-9235) to more than 250 feet (76.2 
meters) below MSL (OFMS 109; Plate 2, cross section F-F', W-19652). The unit is thickest in the southeastern portion of the study area and ranges from 265 feet (80.8 meters) thick (OFMS 109; Plate 2, cross-section F-F', W-11570) to approximately 30 feet thick (9.1 meters; OFMS 109; Plate 2, cross-section A-A', W-15380). The Arcadia Formation grades into undifferentiated Hawthorn Group sediments in southern Pinellas County (OFMS 109; Plate 2, cross-section D-D'). See section on undifferentiated Hawthorn Group below for more discussion.

\section{Tampa Member}

The upper Oligocene to lower Miocene (Brewster-Wingard et al., 1997) Tampa Member of the Arcadia Formation (That) varies from white to yellowish gray in color and ranges from a wackestone to packstone with varying amounts of quartz sand, silt, and clay (Scott, 1988). Phosphate is often absent in the Tampa Member, making this one of the characteristics that aid in distinguishing it from undifferentiated Arcadia Formation sediments. Phosphate can be present, though in amounts less than three percent. Dolomite, silt, and clay are occasionally present though rare. Dolomite is mostly observed near contacts with overlying and/or underlying units such as the Arcadia Formation or dolomitized sections of the Suwannee Limestone. Occasional thin clay beds were observed in core, and less notably in cuttings, throughout the area. Quartz sand content in the carbonate sections varies from two percent to thirty percent. Sand beds can be found intermittently within the unit. Chert, silicified limestone, and silicified corals are not uncommon in the Tampa Member. Silicified (agatized) coral is commonly found at Ballast Point along the western shore of Hillsborough Bay. Silicified corals are formed when calcium carbonate undergoes dissolution and is replaced with cryptocrystalline quartz through precipitation. According to Weisbord (1973), often the "original calcareous structure has been partially or wholly dissolved and the replacing siliceous deposit is so obscurative as to render identification of the taxon difficult or impossible." Fossil molds of foraminifera, mollusks, and gastropods are all common within the Tampa Member. Porosity of the unit is generally intergranular and moldic.

In the study area, the Tampa Member overlies the Suwannee Limestone and the contact appears to be locally conformable. At times, however, this contact can be difficult to identify (see above reference to "SuwaTampaHaw"). In these cases, the unit is differentiated by a transition from quartz sand in minor amounts to the absence of quartz sand, indicating the top of the Suwannee Limestone. In many wells, the transition between the Tampa Member and the overlying undifferentiated Arcadia Formation is marked by a transition from phosphatic dolostone (Arcadia Formation) to a limestone with little to no phosphate content (Tampa Member, Arcadia Formation). In parts of Pinellas and Hillsborough counties, the unit is unconformably overlain by undifferentiated clays, dolosilts, and dolostones of the undifferentiated Hawthorn Group (Th), and undifferentiated Quaternary sands and clays (Qu). In the eastern portion of the study area, the Tampa Member is unconformably overlain by the Peace River Formation. Along the updip erosional pinchout of the Tampa Member, where it forms an irregular subcrop contact with the Suwannee Limestone, the top of the FAS generally coincides with the uppermost carbonate unit occurrence (Arthur et al., 2008).

In the study area, the top of the Tampa Member ranges from approximately 30 feet (9.1 meters) above MSL (OFMS 109; Plate 2, cross-section E-E', W-802) to approximately 275 feet (83.8 meters) below MSL (OFMS 109; Plate 2, cross-sections E-E', W-19338). The maximum observed thickness of the Tampa Member is 160 feet (48.8 meters) in W-13515 (OFMS 109; Plate 2, cross-sections B-B' and E-E'). The Tampa Member is thinnest at 30 feet (9.1 meters) in W10577 (OFMS 109; Plate 2, cross-sections A-A' and F-F') where the Nocatee Member is present. 


\section{FLORIDA GEOLOGICAL SURVEY}

\section{Nocatee Member}

The upper Oligocene (Brewster-Wingard et al., 1997) Nocatee Member of the Arcadia Formation (Than) is predominantly a siliciclastic unit consisting primarily of quartz sand and clay beds with occasional phosphate, silt, clay, limestone, and dolomite (Scott, 1988). The Nocatee Member is entirely a subsurface unit in Florida. Where present, it forms the base of the Arcadia Formation. The Nocatee Member was only recognized in five wells along the easternmost part of the study area (OFMS 109; Plate 2, cross-section A-A' and F-F'). Arthur et al., (2008) show the extents of the unit just barely coming into the mapped area. The Nocatee Member is differentiated from the overlying Tampa Member and underlying Suwannee Limestone by a significant increase in quartz sand content and lower percentage of calcareous matrix. This unit is also marked by an increase in light olive gray to light greenish gray clay beds. In the mapped area, the top of the unit ranges from 40 feet (12.2 meters) below MSL (OFMS 109; Plate 2, cross-section A-A' and F-F', W-10577) to 64 feet (19.5 meters) below MSL (OFMS 109; Plate 2, cross-section F-F'; W-18816). The unit ranges in thickness from 60 feet (18.3 meters) to 25 feet (7.6 meters; OFMS 109; Plate 2, cross-section F-F'; W-10577 and W-18816). The Nocatee Member of the Arcadia Formation, where present, forms part of the FAS (Southeastern Geological Society Ad Hoc Committee on Florida Hydrostratigraphic Unit Definition, 1986).

\section{Peace River Formation}

The middle Miocene to lower Pliocene (Scott, 1988; Covington, 1993) Peace River Formation (Thp) is comprised of yellowish gray to olive gray, interbedded sands, clays and carbonates with the siliciclastic component being dominant (Scott, 1988). Phosphate sand and gravel are most common in the uppermost beds, although they are generally interspersed throughout the unit. The Peace River Formation contains a diverse fossil assemblage of marine and terrestrial fauna (e.g., shark teeth, ray spines, horse teeth, dugong, and whale ribs), particularly within the Bone Valley Member. Porosity types in the formation are generally intergranular.

The Peace River Formation unconformably overlies the Tampa Member of the Arcadia Formation in the central portion of the mapped area, and the Arcadia Formation in the eastern portion of the mapped area (OFMS 109, Plate 2). The contact between the Peace River Formation and Arcadia Formation can be problematic in the southwestern portion of the study area. In this area, the two units may appear to be conformable, with phosphate-rich siliciclastics grading with depth into more siliciclastic-interbedded carbonates containing generally finer-grained and less abundant phosphate (Arthur et al., 2008). In such cases, the lower contact of the Peace River Formation is estimated based on sedimentary structures as well as a best approximation of where the overall lithologic sequence becomes more carbonate dominant (Scott, 1988). In the northeastern portion of the study area, the contact is readily recognized at the first occurrence of a light colored, phosphatic and quartz sandy dolostone.

The Peace River Formation ranges from 132 feet (40.2 meters) above MSL in W-9235 (OFMS 109; Plate 2, Cross Section F-F') to 39 feet (11.9 meters) below MSL in W-13515 (OFMS 109; Plate 2, Cross-section B-B' and E-E'). Thicknesses range from 136 feet (41.5 meters) in W16740 (OFMS 109; Plate 2, Cross-section C-C') to six feet (1.8 meters) in W-17113 (OFMS 109; Plate 2, Cross-section A-A').

The Peace River Formation is within the upper portion of the Intermediate Aquifer System/Confining Unit (IAS/ICU) and regionally is a confining to semi-confining lithostratigraphic unit. The Peace River Formation and undifferentiated Hawthorn Group 
sediments comprise a low-permeability confining to semi-confining facies within the IAS/ICU within the study area. (Southeastern Geological Society Ad Hoc Committee on Florida Hydrostratigraphic Unit Definition, 1986).

\section{Bone Valley Member}

The middle Miocene to lower Pliocene (Webb and Crissinger, 1983) Bone Valley Member of the Peace River Formation (Thpb) is lithologically very similar to the Peace River Formation. The lithology of the Bone Valley Member differs in that it contains higher concentrations of coarse-grained phosphate (more than 30 percent by volume), ranging up to gravel-size nodules. Some pebble sized grains show evidence of reworking, boring structures and multiple stages of phosphatization. Phosphate coloration ranges from black and brown to cream and white. The nonphosphorite component of the Bone Valley Member is comprised of quartz sand and clay (e.g. palygorskite and sepiolite; Scott, 1988), occasionally with minor amounts of dolomite. Carbonate beds are not present; however, limestone and dolostone cobbles may be present (Tom Scott, personal communication, 2005). According to Scott (1988, p. 87), "the occurrence of phosphate gravels in the Bone Valley Member is the most lithologically important factor in the separation of the member from the remainder of the Peace River Formation.” Scott (1988) also notes that the contact between the Bone Valley Member and the Peace River Formation is gradational, both laterally and vertically. While the Bone Valley Member can often be separated from the remainder of the Peace River Formation in cores and in mines, it is rarely possible to differentiate the unit in cuttings.

After looking at hundreds of sets of cuttings and dozens of cores throughout the study area the authors determined that the Bone Valley Member, as defined by Scott (1988), could not reliably be mapped at this scale in the study area. This is due to a combination of several factors including the gradational nature of the contacts, lithological similarities between the Bone Valley Member and the Peace River Formation, poor core control, and significant amounts of phosphate mining activities during the last century.

Of the 230 boreholes located in the area historically mapped as the Bone Valley Member, only a small fraction of the wells had sediment matching the lithostratigraphic definition of the Bone Valley Member of Scott (1988). Arthur et al. (2008) only had eleven wells within the current map area which identified the Bone Valley Member as being present. It should be noted that the areas mapped as Bone Valley Member in Arthur et al. (2008) and Scott (1988) were based on a very limited number of wells, and the boundaries of the unit were heavily influenced by the presence of phosphate mines. Mining in the phosphate district is largely driven by economics and thus they historically mined phosphate-rich zones, not necessarily the Bone Valley Member lithostratigraphic unit as defined by Scott (1988).

The eastern part of the mapped area has been extensively mined for phosphate (Figure 7) going as far back as 1890 (Sellards, 1915). As a result, much of the area formerly mapped as Bone Valley Member by Scott (1988) and Arthur et al. (2008) has been removed and/or reclaimed, and the surficial sediments no longer truly represent the original lithology. This also proved to be an issue when working with core and cutting samples that have been collected over the span of the past 100 years. These samples often had incomplete location and elevation information, making the determination of the top of the Bone Valley Member problematic at best. Without reliable information on boreholes located in mined areas and specific locations and elevations, the authors were unable to determine if the various samples examined were collected pre- or post-mining in many instances. After much discussion with various staff geologists (including Tom Scott), it was 
determined that it was best to map the area as Peace River Formation and forego attempts to delineate the Bone Valley Member at this scale. The reader is referred to Scott (1988) and Arthur et al. (2008) for the former extents and additional discussion of the Bone Valley Member.

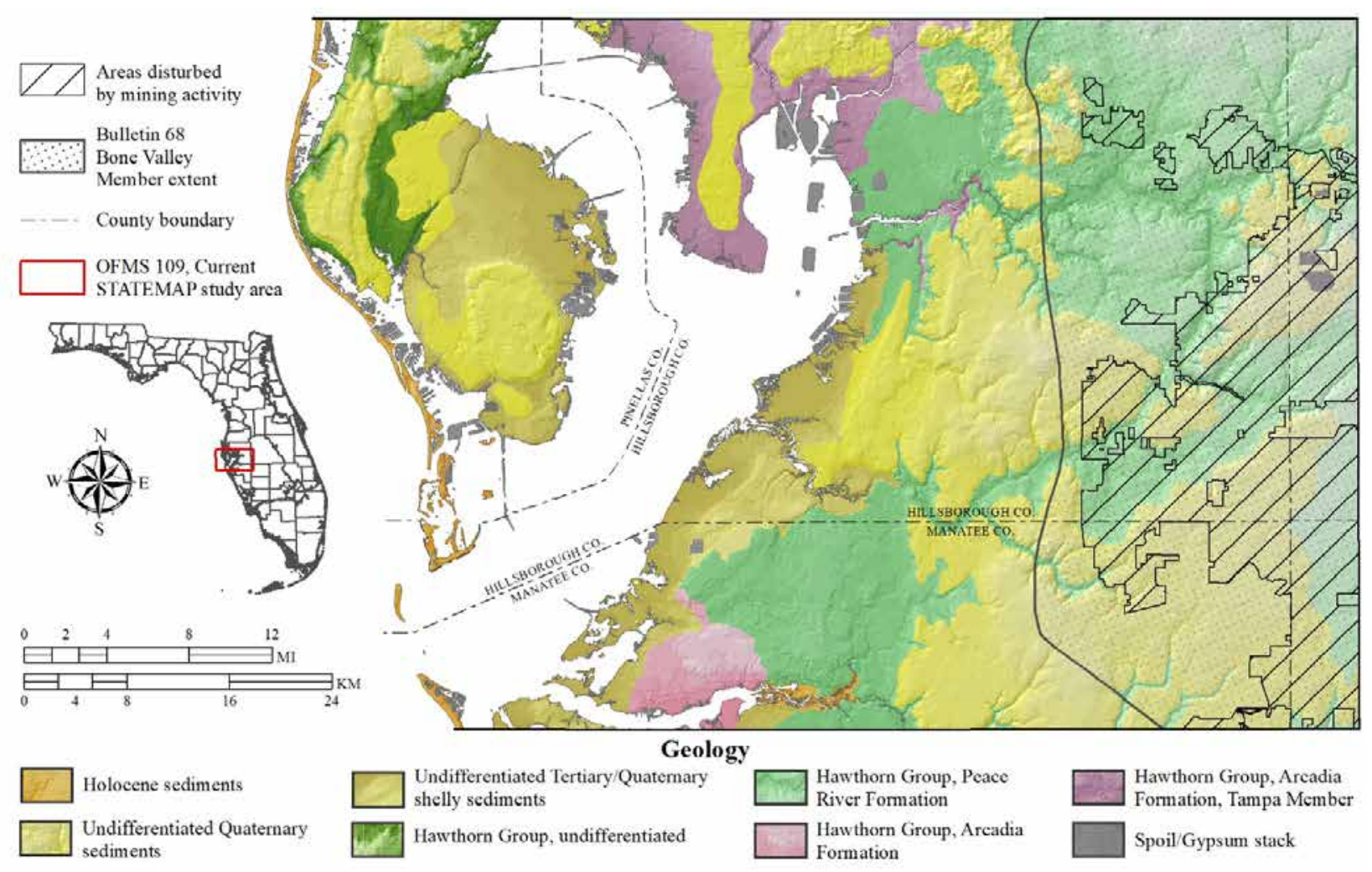

Figure 7. Mined areas with extents of Bone Valley Member from Arthur et al. (2008)

Hawthorn Group (undifferentiated)

The Hawthorn Group (undifferentiated) is mapped throughout Pinellas County following the convention of Scott et al. (2001). Similar lithologies of the lower Peace River Formation and upper Arcadia Formation, combined with post-depositional reworking of Hawthorn Group sediments, makes consistently differentiating the Peace River and Arcadia formations difficult in cores and impossible in cuttings. Based solely upon lithology, due to overall siliciclastic content, many of these sediments could be considered as Peace River Formation. However; the chert, agatized corals, and intervals dominated by dolosilt and dolostone are more typical of an Arcadia Formation lithology. Additionally, the Tampa Member of the Arcadia Formation underlies these undifferentiated Hawthorn Group sediments in Pinellas County.

Undifferentiated Hawthorn Group (Th) sediments lie unconformably above upper Oligocene to lower Miocene (Brewster-Wingard et al., 1997; Scott, et al., 2001) Tampa Member of the Arcadia Formation (That; OFMS 109; Plate 2, Cross Section A-A', B-B', and D-D'). They are light olive gray and blue gray in unweathered sections and brownish gray to grayish orange and reddish brown to reddish gray in weathered sections. They consist of poorly- to moderatelyconsolidated, clayey sands to silty clays, and relatively pure clays with minor phosphate due to leaching and transport (Scott, 2001). In addition to these clays, the present study noted that the unit also contains dolosilts, dolostones, and variable (but typically low) concentrations of 
phosphatic sand with occasional phosphatic gravel. The clays are often expansive, but are, at times, silicified. Agatized corals and chert are also present.

Where present, undifferentiated Hawthorn Group sediments unconformably overlie the Tampa Member of the Arcadia Formation (Scott et al., 2001). They are at times unconformably overlain by undifferentiated Quaternary sediments or undifferentiated Tertiary/Quaternary shelly sediments (OFMS 109, Plates 1 and 2). The undifferentiated Hawthorn Group sediments transitionally grade into undifferentiated Arcadia Formation towards the south in Pinellas County (OFMS 109; Plate 2, W-17600/W-252).

Within the study area, the top of the unit ranges from 25 feet (7.6 meters) above MSL to 110 feet (33.5 meters) below MSL (OFMS 109; Plate 2, cross-section D-D', W-3413). The undifferentiated Hawthorn Group ranges from 100 feet thick (30.5 meters; OFMS 109; Plate 2, cross-section D-D', W-14778) to 20 feet thick (6.1 meters; OFMS 109; Plate 2, cross-section BB', W-3118).

The undifferentiated Hawthorn Group sediments generally have low permeability and form part of the IAS/ICU (Southeastern Geological Society Ad Hoc Committee on Florida Hydrostratigraphic Unit Definition, 1986).

\section{Tertiary/Quaternary Systems}

\section{Pliocene/Pleistocene Series}

Undifferentiated Tertiary/Quaternary shelly sediments

Undifferentiated Tertiary/Quaternary shelly sediments (TQsu) disconformably overlie the Arcadia Formation or the Peace River Formation throughout western Manatee and southwestern Hillsborough counties east of Tampa Bay. TQsu sediments disconformably overlie undifferentiated Hawthorn Group (Th) in Pinellas County. There are problems in mapping these sediments as separate units because their historical definition is based on biostratigraphic, not lithostratigraphic, criteria (Scott and Allmon, 1990; Scott and Wingard 1995). Scott and Campbell (1993) informally applied the name Okeechobee formation to these sediments in an effort to provide a lithostratigraphic framework. McCartan and Moy (1995) mapped several units south of this area (Sarasota quadrangle) based upon inferred ages from fossils, stratigraphic position, and isotope age dates. Due to the similar lithologies of these units, difficulties encountered in attempting to differentiate them in drill cuttings, and the fact that the Okeechobee formation was never formalized, they are placed within the TQsu on this map.

The undifferentiated Tertiary/Quaternary shelly sediments include sediments from the Pinecrest Member (Tamiami Formation), Caloosahatchee Formation, Bermont formation, and Fort Thompson Formation. Lithologies of the TQsu consist of clay, silt, sand, phosphate, shells, and carbonate in varying admixtures. The unit may range from a shelly sand with carbonate and clay, to shell beds with accessory carbonate, sand and clay. Phosphate is commonly associated with the unit, having been reworked from the underlying Hawthorn Group sediments. Virtually all of the individual lithologies are fossiliferous, containing some of the most macrofossiliferous sediments in the Gulf and Atlantic Coastal Plain. For discussion of these sediments and the fossils contained in them, refer to Petuch (1982), Scott and Allmon (1990), Scott and Wingard (1995), and Hulbert et al. (1995a, 1995b). In western Manatee County, south of I-275, the TQsu becomes thinner, in most cases less than ten feet (3.1 meters), and intermittent. Field and borehole data here indicate that the area is a mix of thin, shallow TQsu, Arcadia Formation, and a mixture of residual sand, 
clay, and phosphate which may in some cases be isolated remnants of Peace River Formation. The authors have decided to map this area as TQsu, but are aware that it could also be mapped as Arcadia Formation with known, intermittent, TQsu present. Additional work and data are needed to most accurately determine which unit should be mapped in this area. Permeable sediments of the undifferentiated Tertiary/Quaternary shelly sediments (TQsu) form part of the surficial aquifer system (SAS) (Southeastern Geological Society Ad Hoc Committee on Florida Hydrostratigraphic Unit Definition, 1986).

\section{Pleistocene to Holocene Series}

\section{Undifferentiated Quaternary sediments}

While not a formally recognized lithostratigraphic unit, undifferentiated Quaternary sediments (Qu), are mapped following the convention of Scott et al. (2001), in order to facilitate a better understanding of Florida's geology. The undifferentiated Quaternary sediments in the mapped area may be highly variable in thickness. Undifferentiated Quaternary sediments (Qu) in the study area lie unconformably on the Peace River Formation, the Arcadia Formation, Tampa Member of the Arcadia Formation, undifferentiated Hawthorn Group, or undifferentiated Tertiary/Quaternary shelly sediments (OFMS 109, Plate 2).

Generally, undifferentiated Quaternary sediments consist of white to gray to orange to brown, fine- to coarse-grained, clean to clayey (usually) unfossiliferous sands, sandy clays and clays with variable admixtures of organics. The undifferentiated Quaternary sediments form part of the SAS (Southeastern Geological Society Ad Hoc Committee on Florida Hydrostratigraphic Unit Definition, 1986). Where these sediments lack clay and overlie the Tampa Member of the Arcadia Formation, they are hydraulically connected to the Floridan aquifer system.

\section{Holocene sediments}

Sediments mapped as Holocene (Qh) may include quartz sands, marls, organics, and minor carbonate sands and mud. They may also include fresh-water gastropods and modern shells. Within the study area, these occur near the Manatee River and along the present coastline in barrier islands on the Gulf of Mexico. Studies by Davis et al. (1992) suggest Holocene age for these barrier islands. The Holocene sediments (Qh) form part of the SAS (Southeastern Geological Society Ad Hoc Committee on Florida Hydrostratigraphic Unit Definition, 1986).

\section{SPOIL}

Areas mapped as spoil include a variety of materials. Extensive human modification of the shorelines throughout the study area have occurred during the past century. Historical late 1930s and early 1940s aerial photographs from the George A. Smathers Library at the University of Florida were accessed for Pinellas (1942 and 1943), Hillsborough (1938), and Manatee (1940) counties. Numerous areas of canal cut and fill construction and development are present, but regions mapped as spoil were limited to those directly impacting change to the historical shorelines and fringing salt marsh and mangroves. Additionally, mining activities in the central Florida phosphate district have created numerous "gypstacks" which are mounds of phosphogypsum derived as byproduct from phosphate processing. These "gypstacks" represent recent, manmade 
materials. Therefore, it was decided to delineate them as spoil on the current maps (OFMS 109, Plates 1 and 2) using a spoil pattern and the letters "GYP" as a label in the mapped polygon.

\section{MINING EFFECTS}

Figure 7 depicts areas subjected to phosphate mining in the mapped quadrangle. The geologic map and cross-sections associated with this product (OFMS 109, plates 1 and 2) are based on field work and borehole data from the FGS Geological Sample Repository. Areas shown as Peace River Formation (Thp) and undifferentiated Quaternary (Qu) in the phosphate mining zones on OFMS 109 (plates 1 and 2) reflect data which are primarily derived from boreholes and historic data. As such, the reader should note that there are differences between the geology as mapped and the surficial geology inside of these mined areas. In some of the mined areas, the undifferentiated Quaternary sediments (dominated by quartz sand) and Peace River Formation have been removed during mining, in some cases multiple times, in the last century. Mining processes in these areas have mixed the undifferentiated Quaternary sediments and quartz sand, unmined phosphate grains, clays, and carbonate materials from the Peace River Formation.

Determination of original ground surface versus mined and reclaimed surfaces is practically impossible and is further complicated by the lack of LiDAR in the region. The DEM in this portion of the map is based on topography derived from USGS 7.5 minute quadrangles from the 1950's through the 1980's, thus the elevations depicted on the cross-sections and maps may not reflect current topography in these mined or reclaimed areas. One example of this is the area around W-9235 (OFMS 109, Plate 2, cross-section F-F'). This borehole, which was likely drilled in the 1960's by Humble Oil Refining Company (the precise date is unknown) and was given to the FGS for archiving in 1969, predated mining in this area. The "gypstacks" shown on the map now exceed 360 feet (109.7 meters) in elevation, but the DEM data for the area only shows a surface elevation of 160 feet (48.8 meters). This area has been mined since the 1970's for phosphate and phosphogypsum has been stored here since the mid-1970's. As such, the authors have decided to map the geology based on borehole data and historic data, showing the areas that are likely disturbed in Figure 7.

\section{HYDROGEOLOGY}

Hydrostratigraphic units within the map area, in ascending order, consist of the FAS, the IAS/ICU, and the SAS (Southeastern Geological Society Ad Hoc Committee on Florida Hydrostratigraphic Unit Definition, 1986). A graphic representation of the hydrostratigraphic units, and their relationship to lithostratigraphic units, can be seen on OFMS 109, Plate 2, Figure 2. The FAS, the primary source for springs and drinking water in the region, is generally comprised of carbonate units of the Avon Park Formation, the Ocala Limestone, the Suwannee Limestone, and the Arcadia Formation (Hawthorn Group). Arthur et al. (2008) provide a more detailed discussion of the FAS in the region. The sands, silts, clays and carbonates of the remainder of the Hawthorn Group comprise the IAS/ICU. The IAS/ICU is highly localized and laterally discontinuous in the study area. The SAS is comprised of TQsu, Qu, and Qh sediments.

Where clayey siliciclastic sediments of the Hawthorn Group and younger units are thick and continuous, they provide confinement for the FAS, but where the clayey siliciclastic sediments of the Hawthorn Group and younger units are thin, missing or lack significant clay component, karst features often occur. 


\section{FLORIDA GEOLOGICAL SURVEY}

\section{DERIVATIVE PRODUCTS}

Several derivative products were developed in the process of completing this project. During the mapping efforts, data from 430 wells with samples were analyzed and used (Appendix A). Formation picks made on these cores and cutting samples, allow creation of structure contour and isopach maps for the top of several units in the area. Additional derivative products anticipated to come from this mapping effort include aquifer vulnerability assessment maps. Data derived from prior STATEMAP products have often been used to augment other Florida Geological Survey and Florida Aquifer Vulnerability Assessment (FAVA) projects in the state (Arthur et al., 2007; Baker et al., 2007).

\section{REFERENCES}

Applin, P., 1951, Possible future petroleum provinces of North America - Florida: American Association of Petroleum Geologists Bulletin, v. 35, p. 405-407.

Applin, P.L., and Applin, E.R., 1944, Regional subsurface stratigraphy and structure of Florida and southern Georgia: American Association of Petroleum Geologists Bulletin, v. 28, p. 16731753.

Applin, P.L., and Applin, E.R., 1965, The Comanche Series and associated rocks in the subsurface in central and south Florida: U.S. Geological Survey Professional Paper 447, 84 p.

Arthur, J.D., and Campbell, K.M., 1993, Geologic map of Pinellas County, Florida: Florida Geological Survey Open-File Map Series 43, Scale: 1:126,720.

Arthur, J.D., Wood, H.A.R., Baker, A.E., Cichon, J.R., and Raines, G.L., 2007, Development and implementation of a Bayesian-based aquifer vulnerability assessment in Florida: Natural Resources Research, v. 16, p. 93-107.

Arthur, J.D., Fischler, C., Kromhout, C., Clayton, J.M., Kelley, G.M., Lee, R.A., Li, L., O’Sullivan, M., Green, R.C., and Werner, C.L., 2008, Hydrogeologic framework of the Southwest Florida Water Management District: Florida Geological Survey Bulletin 68, 102 p.

Baker, A.E., Wood, H.A.R., and Cichon, J.R., 2007, The Marion County Aquifer Vulnerability Assessment: unpublished report submitted to Marion County Board of County Commissioners in fulfillment of Marion County Project No. SS06-01, March 2007, 42 p.

Beck, B.F., and Sinclair, W.C., 1986, Sinkholes in Florida: An introduction: University of Central Florida, Orlando, Florida Sinkhole Research Institute Report 85-86-4, 16 p.

Brewster-Wingard, G.L., Scott, T.M., Edwards, L.E., Weedman, S.D., and Simmons, K.R., 1997, Reinterpretation of the peninsular Florida Oligocene: an integrated stratigraphic approach: Sedimentary Geology, v. 108, p. 207-228. 
Bryan, J.R., 2004, Larger foraminifera: Introduction, biology, ecology, taxonomic and stratigraphic listings and comments on Florida fossil assemblages: Gainesville, Florida Paleontological Society, Florida Fossil Invertebrates, Part 6, 28 p.

Budd, D.A., 2002, The relative roles of compaction and early cementation in the destruction of permeability in carbonate grainstones: A case study from the Paleogene of west-central Florida, USA: Journal of Sedimentary Research, v. 72, p. 116-128.

Campbell, K.M., 1993a, Geologic map of Manatee County, Florida: Florida Geological Survey Open-File Map Series 50, Scale 1:126,720.

1993b, Geologic map of Polk County, Florida: Florida Geological Survey OpenFile Map Series 46, Scale 1:126,720.

Campbell, K.M., and Arthur, J.D., 1993, Geologic Map of Hillsborough County, Florida: Florida Geological Survey Open-File Map Series 45, Scale: 1:126,720.

Cooke, C.W., 1945, Geology of Florida: Florida Geological Survey Bulletin 29, 342 p.

Cooke, C.W., and Mansfield, W.C., 1936, Suwannee limestone of Florida (abstract): Geological Society of America Proceedings 1935, p. 71-72.

Copeland, R., Doran, N.A., White, A.J., and Upchurch, S.B., 2009, Regional and statewide trends in Florida's spring and well groundwater quality (1991-2003): Florida Geological Survey Bulletin 69, 203 p.

Covington, J.M., 1993, Neogene nannofossils of Florida, in Zullo, V.A., Harris, W.B., Scott, T.M., and Portell, R.W., eds., The Neogene of Florida and adjacent regions: Florida Geological Survey Special Publication 37, 112 p.

Dall, W.H., and Harris, G.D., 1892, Correlation papers, Neocene: U.S. Geological Survey Bulletin 84, $349 \mathrm{p}$.

Davis, R.A., Jr., Hine, A.C., and Shinn, E.A., 1992, Holocene coastal development on the Florida peninsula, in Fletcher, C.H., III and Wehnmiller, J.F., eds., Quaternary Coasts of the United States: Marine and Lacustrine Systems, SEPM Special Publication 48, p. 193-212.

Duncan, D.S., Locker, S.D., Brooks, G.R., Hine, A.C., and Doyle, L.J., 2003, Mixed carbonatesiliciclastic infilling of a Neogene carbonate shelf-valley system: Tampa Bay, west-central Florida: Marine Geology, v. 200, p. 125-156.

Espenshade, G.H., and Spencer, C.W., 1963, Geology of phosphate deposits of northern peninsular Florida: United States Geological Survey Bulletin 1118, 115 p. 


\section{FLORIDA GEOLOGICAL SURVEY}

Evans, W.L., III, Green, R.C., Bryan, J.R., and Paul, D.T., 2004, Geologic map of the western portion of the USGS 1:100,000 scale Gainesville quadrangle, northern Florida: Florida Geological Survey Open-File Map Series 93, scale 1:100,000, 2 plates.

Green, R.C., Scott, T.M., Campbell, K.M., Arthur, J.D., and Means, G.H., 1997, Surficial and bedrock geology of the western portion of the USGS 1:100,000 scale Sarasota quadrangle, Florida: Florida Geological Survey Open-File Map Series 86, 2 maps, 6 cross-sections.

Green, R.C., Scott, T.M., Campbell, K.M., and Means, G.H., 1998, Surficial and Bedrock Geology of the eastern portion of the USGS 1:100,000 scale Sarasota quadrangle and the western portion of the USGS 1:100,000 scale Arcadia quadrangle, Florida: Florida Geological Survey OpenFile Map Series 87, 2 maps, 6 cross-sections.

Green, R.C., Evans, W.L., III, Paul , D.T., and Scott, T.M., 2005, Geologic map of the eastern portion of the USGS Gainesville 30 x 60 minute quadrangle, northern Florida: Florida Geological Survey Open-File Map Series 94, scale 1:100,000, 2 plates.

Green, R.C., Paul, D.T., Evans, W.L. III, Scott, T.M., and Petrushak, S.B., 2006, Geologic map of the western portion of the USGS 1:100,000 scale Lake City quadrangle, northern Florida: Florida Geological Survey Open-File Map Series No. 97, 2 plates.

Green, R.C., Paul, D.T., Petrushak, S.B., Kromhout, C., and Scott, T.M., 2007a, Geologic map of the eastern portion of the USGS Perry 30 x 60 minute quadrangle, northern Florida: Florida Geological Survey Open-File Map Series 98, 3 plates.

Green, R.C., Paul, D.T., Petrushak, S.B., Kromhout, C., and Scott, T.M., 2007b, Text to accompany geologic map of the eastern portion of the USGS Perry 30 x 60 minute quadrangle, northern Florida, Open File Map Series 98: Florida Geological Survey Open-File Report 91, 32 pages.

Green, R.C., Paul, D.T., Wagner, D.J., Kromhout, C., and Scott, T.M., 2008a, Geologic map of the western portion of the USGS Perry 30 x 60 minute quadrangle, northern Florida: Florida Geological Survey Open-File Map Series 99, 3 plates.

Green, R.C., Paul, D.T., and Scott, T.M., 2008b, Text to accompany geologic map of the western portion of the USGS Perry 30 x 60 minute quadrangle, northern Florida Open-File Map Series 99: Florida Geological Survey Open File-Report 92, 35 p.

Green, R.C., Williams, C.P., Paul, D.T., Kromhout, C.K., and Scott, T.M., 2009a, Geologic map of the eastern portion of the USGS Ocala 30 x 60 minute quadrangle, north-central Florida: Florida Geological Survey Open File Map Series 100, 3 plates, scale 1:100,000.

Green, R.C., Williams, C.P., Paul, D.T., Kromhout, C.K., and Scott, T.M., 2009b, Text to accompany geologic map of the eastern portion of the USGS Ocala 30 x 60 minute quadrangle, north-central Florida: Florida Geological Survey Open File Report 93, 29 p. 
Green, R.C., Williams, C.P., Flor, A.D., Paul, D.T. Kromhout, C.K.,and Scott, T.M., 2010, Geologic map of the western portion of the USGS Ocala 30 x 60 minute quadrangle, northcentral Florida: Florida Geological Survey Open File Map Series 101, scale 1:100,000.

Green, R.C., Williams, C.P., Burdette, K.E., Bassett, S.W., Flor, A.D., and Paul, D.T., 2011, Geologic map of the eastern portion of the USGS Inverness 30 x 60 minute quadrangle, central Florida: Florida Geological Survey Open-File Map Series 102, scale 1:100,000, 3 plates.

Green, R.C., Evans, W.L., III, Williams, C.P., Kromhout, C., Bassett, S.W., and Hannon, L.M., 2012a, Geologic map of the USGS Tarpon Springs 30 x 60 minute quadrangle, central Florida: Florida Geological Survey Open-File Map Series 104, scale 1:100,000, 3 plates.

Green, R.C., Evans, W.L., III, Williams, C.P., Kromhout, C., and Bassett, S.W., 2012b, Text to accompany Geologic map of the USGS Tarpon Springs 30 x 60 minute quadrangle, central Florida: Florida Geological Survey Open-File Report 98, 43p.

Green, R.C., Evans, W.L, Bassett, S.W., and Hannon, L.M., 2013a, Geologic map of the USGS Daytona Beach 30 x 60 minute quadrangle, northeast Florida: Florida Geological Survey Open File Map Series 105, scale 1:100,000.

Green, R.C., Evans, W.L, and Bassett, S.W., 2013b, Text to accompany geologic map of the USGS Daytona Beach 30 x 60 minute quadrangle, northeast Florida: Florida Geological Survey Open File Report 101, 37 p.

Green, R.C., Williams, C.P., Bambach, P.W., Hannon, L.M., Apolinar, B., Campbell, K.M., and Dyer, S.B., 2015a, Geologic map of the USGS Orlando 30 x 60 minute quadrangle, central Florida: Florida Geological Survey Open File Map Series 107, scale 1:100,000.

Green, R.C., Williams, C.P., Bambach, P.W., Hannon, L.M., Apolinar, B., Campbell, K.M., and Dyer, S.B., 2015b, Text to accompany geologic map of the USGS Orlando 30 x 60 minute quadrangle, central Florida: Florida Geological Survey Open File Report 104, 37 p.

Hine, A.C., Suthard, B., Locker, S.D., Cunningham, K.J., Duncan, D.S., Evans, M., and Morton, R.A., 2009, Karst subbasins and their relation to the transport of Tertiary siliciclastic sediments on the Florida Platform, in Swart, P.K, Eberli, G.P., and McKenzie, J.A., eds., Perspectives in sedimentary geology: A tribute to the career of Robert N. Ginsburg: Wiley-Blackwell, International Association of Sedimentologists, Special Publication, v. 41, p. 179-197.

Hopkins, O.B., 1920, Drilling for oil in Florida: U.S. Geological Survey Press Bulletin, April, 1920.

Hulbert, R.C., Jr., Morgan, G.S., and Webb, D.S., eds., 1995a, Paleontology and geology of the Leisey Shell Pits, early Pleistocene of Florida: Florida Museum of Natural History Bulletin 37, Part I, Nos. 1-10, pp. 1-344. 
Hulbert, R.C., Jr., Morgan, G.S., and Webb, D.S., eds., 1995b, Paleontology and Geology of the Leisey Shell Pits, Early Pleistocene of Florida: Florida Museum of Natural History Bulletin 37, Part II, Nos. 11-20, pp. 345-660.

Hydrologic Unit Codes: Basins, 1993: Tallahassee: Florida Department of Environmental Protection, [vector digital data file].

Jones, G.W., Upchurch, S.B., and Champion, K.M., 1996, Origin of nitrate in groundwater discharging from Rainbow Springs, Marion County, Florida: Brooksville, Southwest Florida Water Management District Report, 155 p.

McCartan, L., and Moy, W., 1995, Geologic map of the Sarasota and Arcadia, Florida, 30 x 60 minute quadrangles: United States Geological Survey Open-File report 95-261, scale 1:100,000, 5 plates.

Miller, J.A., 1986, Hydrogeologic framework of the Floridan aquifer system in Florida and in parts of Georgia, Alabama, and South Carolina: Regional Aquifer-System Analysis: U.S. Geological Survey Professional Paper 1403-B, 91 p., 33 plates.

Missimer, T.M., and Maliva, R.G., 2017, Late Miocene fluvial sediment transport from the southern Appalachian Mountains to southern Florida: An example of an old mountain belt sediment production surge, Sedimentology. DOI: 10.1111/sed. 12377

National Oceanic and Atmospheric Administration, 2012, Observed Weather Reports: Record Event Report: Tampa/Lakeland: June 26, 2012: National Oceanic and Atmospheric Administration: National Weather Service: National Climatic Data Center: Record Report, http://www.nws.noaa.gov/climate/getclimate.php?wfo=tbw [August, 2012]

Petuch, E.J., 1982, Notes on the molluscan paleoecology of the Pinecrest Beds at Sarasota, Florida with the description of Pyruella, a stratigraphically important new genus (Gastropoda: Melongenidae): Proceedings of the Academy of Natural Sciences of Philadelphia, V. 134, p. 12-30.

Phelps, G.G., 1994, Hydrogeology, water quality and potential for contamination of the Upper Floridan Aquifer in the Silver Springs Ground-Water Basin, Central Marion County, Florida: U.S. Geological Survey Water-Resources Investigations Report 92-4159, 69 p.

, 2004, Chemistry of groundwater in the Silver Springs Basin, with an emphasis on nitrate: U.S. Geological Survey Scientific Investigations Report 2004-5144, 54 p.

Poucher, S., and Copeland, R., 2006, Speleological and karst glossary of Florida and the Caribbean: Gainesville, University Press of Florida, 196 p.

Puri, H.S., and Vernon, R.O., 1964, Summary of the geology of Florida and a guidebook to the classic exposures: Florida Geological Survey Special Publication 5, revised, 312 p. 
Schmidt, W., 1984, Neogene stratigraphy and geologic history of the Apalachicola Embayment: Florida Geological Survey Bulletin 58, 146 p.

Scott, T.M., 1981a, The paleo-extent of the Miocene Hawthorn Formation in peninsular Florida [abstract]: Florida Scientist, v. 44, Supplement 1, p. 42.

, 1981b, The Hawthorn Formation of North Florida: Southeastern Geological Society, Field Conference Guidebook, v. 23, p. 15-23.

, 1988, The lithostratigraphy of the Hawthorn Group (Miocene) of Florida: Florida Geological Survey Bulletin 59, 148 p.

, 1991a, Depositional patterns of the Hawthorn Group in Florida: Geological Society of America Abstracts with Programs, v. 23, no. 1, p. 126.

, 1991b, A geological overview, in Scott, T.M., Lloyd, J.M., and Maddox, G.L., eds., Florida's ground-water quality monitoring program, hydrogeologic framework: Florida Geological Survey Special Publication 32, 97 p.

, 1997, Miocene to Holocene history of Florida, in Randazzo, A.F., and Jones, D.S., eds., The Geology of Florida: Gainesville, University Press of Florida, p. 57-67.

, 2001, Text to accompany the geologic map of Florida: Florida Geological Survey Open-File Report 80, 29 p.

Scott, T.M., and Campbell, K.M., 1993, Geologic map of Hardee County, Florida: Florida Geological Survey Open-File Map Series 51, Scale 1:126,760.

Scott, T.M., Campbell, K.M., Rupert, F.R., Arthur, J.A., Green, R.C., Means, G.H., Missimer, T.M., Lloyd, J.M., and Duncan, J.G., 2001, Geologic map of Florida: Florida Geological Survey Map Series 146, scale 1:750,000.

Scott, T.M., and Allmon, W., (eds.), 1990, Plio-Pleistocene stratigraphy and paleontology of south Florida: Southeastern Geological Society Field Trip Guidebook 31, unpaginated.

Scott, T.M., Means, G.H., Means, R.C., and Meegan R.P., 2002, First magnitude springs of Florida: Florida Geological Survey Open-File Report 85, 138 p.

Scott, T.M., and Wingard, G.L., 1995, Facies, fossils, and time - A discussion of the litho- and biostratigraphic problems in the Plio-Pleistocene sediments in southern Florida: in Scott, T.M., 1995, Compiler, Stratigraphy and paleontology of the Plio-Pleistocene shell beds, southwest Florida: Southeastern Geological Society Guidebook no. 35, unpaginated.

Sellards, E.H., 1915, The pebble phosphates of Florida: Florida Geological Survey Annual Report 7, p. 29-116. 


\section{FLORIDA GEOLOGICAL SURVEY}

Sinclair, W.C., and Stewart, J.W., 1985, Sinkhole type, development, and distribution in Florida: Florida Geological Survey Map Series 110, scale 30 miles to 1 inch.

Southeastern Geological Society Ad Hoc Committee on Florida Hydrostratigraphic Unit Definition, 1986, Hydrogeological units of Florida: Florida Geological Survey Special Publication 28, 8 p.

SWFWMD, 2010, Frost-Freeze-FAQs: Southwest Florida Water Management District: http://www.swfwmd.state.fl.us/emergency/frost-freeze/Frost-Freeze-FAQs.pdf [August, 2012)]

Tihansky, A.B., 1999, Sinkholes, west-central Florida: U.S. Geological Survey Circular 1182, 20 p.

Tyler, D., Zawada, D.G., Nayegandhi, A., Brock, J.C., Crane, M.P., Yates, K.K., and Smith, K.E.L., 2007, Topobathymetric data for Tampa Bay, Florida: U.S. Geological Survey OpenFile Report 2007-1051 (revised), scale 1:80,000.

Upchurch, S.B., Strom, R.N., and Nuckels, M.G., 1982, Silicification of Miocene rocks from central Florida, in Scott, T.M., and Upchurch, S.B., eds., Miocene of the southeastern United States: Florida Geological Survey Special Publication 25, p. 251-284

Upchurch, S.B., Champion, K.M., Schnieder, J.C., Hornsby, D., Ceryak, R., and Zwanka, W., 2004, Defining springshed boundaries and water-quality domains near first-magnitude springs in north Florida [abstract]: Florida Scientist, v. 67, Supplement 1, p. 52

U.S. Geological Survey, 1981, 1:100,000-scale metric topographic map of Saint Petersburg, Florida: Reston, U.S. Geological Survey, 1 sheet.

Vernon, R.O., 1951, Surface occurrences of geologic formations in Florida (geologic map): Florida Geological Survey Map Series 3, 1 sheet, scale approximately 48 miles to 1 inch.

Waltham, T., Bell, F., and Culshaw, M., 2005, Sinkholes and subsidence, karst and cavernous rocks in engineering and construction: Chichester, Praxis Publishing Ltd., 382 p.

Webb, S.D., and Crissinger, D.B., 1983, Stratigraphy and vertebrate paleontology of the central and southern phosphate districts of Florida, in The Central Florida Phosphate District - Field Trip Guidebook, Geological Society of America, Southeastern Section Annual Meeting, p. 2872.

Weisbord, N.E., 1973, New and little-known corals from the Tampa Formation of Florida: Florida Geological Survey Bulletin 56, 146 p.

White, W.A., 1970, The geomorphology of the Florida peninsula: Florida Geological Survey Bulletin 51, 164 p. 
Williams, C.P., Green, R.C., Flor, A.D., Scott, T.M, and Kromhout, C.K., 2010, Text to accompany geologic map of the western portion of the USGS Ocala 30 x 60 minute quadrangle, north-central Florida: Florida Geological Survey Open File Report 94, 29 p.

Williams, C.P., Burdette, K.E., Green, R.C., Bassett, S.W., Flor, A.D., and Paul, D.T., 2011, Text to accompany geologic map of the eastern portion of the USGS Inverness $30 \times 60$ minute quadrangle, central Florida: Florida Geological Survey Open-File Report 96, 40 p.

Williams, C.P., Green, R.C., Bassett, S.W., Hannon, L.M., and Flor, A.D., 2012, Geologic map of the western portion of the USGS Inverness 30 x 60 minute quadrangle, central Florida: Florida Geological Survey Open-File Map Series 103, scale 1:100,000, 3 plates.

Williams, C.P., and Green, R.C., 2012, Text to accompany geologic map of the western portion of the USGS Inverness 30 x 60 minute quadrangle, central Florida: Florida Geological Survey Open-File Report 97, 29 p.

Williams, C.P., Scott, T.M., Hannon, L.M., and Paul, D.T., (in preparation), Geomorphic map of Florida: Florida Geological Survey, scale 1:750,000.

Williams, K.E., Nicol, D., and Randazzo, A.F., 1977, The geology of the western part of Alachua County, Florida: Florida Geological Survey Report of Investigation 85, 97 p.

Winston, G.O., 1971, Regional structure, stratigraphy and oil possibilities of the South Florida basin: Gulf Coast Association of Geological Societies Transactions, v. 21, p. 15-29.

\section{ACKNOWLEDGEMENTS}

The authors wish to extend thanks to the personnel that assisted with permitting and access to lands for drill sites. Bryon Maxwell, park manager of Alafia River State Park, was helpful in drill site selection and allowing the drill crew access to seldom used back roads in order to access the site. Karen Rogers, with Florida State Parks, made the research and collection permitting process quick and easy. Deena S. Woodward, with the Division of Historical Resources, rushed assistance in reviewing the proposed Alafia River State Park drill site for clearance of historical significance. Michael Elswick, Natural Resources Decision Manager of Dutette Park, invested significant time in assisting with access to the park and specific site location selection for core samples collected on the premises.

Alex Lamarche provided office assistance and processed field samples. Charles Boyd assisted with well location verification, sample verification, and compilation of historic data that was utilized for the project. Special thanks to Eric Thomas who operated the drill rig for many week-long trips, as well as Jesse Hurd, Frank Rush, and Ken Campbell who provided field support for drilling operations. Dave Paul and Scott Barrett Dyer assisted in logging of boreholes. Clint Kromhout and Harley Means operated boats for field work allowing samples to be collected in areas where they would have been otherwise unobtainable. Levi Hannon assisted in fieldwork. Jared Raff and Brian Mudryk assisted in the identification, querying, and vetting of phosphate and mined data within the Saint Petersburg quadrangle. Jared used GIS to compare the elevation values of high resolution LiDAR data to coarser digital elevation models in order to highlight potentially 
mined polygon features. Brian aided in the collection, vetting, aggregation of mining data from the DEP Mining and Mitigation Section, Water Resource Management Division.

Guy H. Means, Clint Kromhout, and Alan Baker reviewed, discussed and edited the product. Tom Scott, Ken Campbell, Clint Kromhout, and Guy H. Means are thanked for their discussions about the Bone Valley Member and how to deal with mapping it for this project. Tom Scott continues to be an asset to geologic mapping in Florida and the ongoing work to revise the state's geomorphic map. This geologic map was funded in part by the Office of the Florida Geological Survey of the Florida Department of Environmental Protection and by the United States Geological Survey National Cooperative Geologic Mapping Program under assistance award number G16AC00295 in Federal fiscal year 2016. 


\section{APPENDIX A: FLORIDA GEOLOGICAL SURVEY WELLS UTILIZED FOR STUDY}

This table lists FGS wells within the boundaries of the USGS Saint Petersburg 30 x 60 minute quadrangle utilized for the project. Due to graphical constraints, not all wells will appear on Plate 1 of OFMS 109. The first 34 wells in the table were utilized for geologic cross-sections and appear on Plates 1 and 2 of OFMS 109.

\begin{tabular}{|c|c|c|c|c|c|c|c|}
\hline $\begin{array}{l}\text { Map } \\
\text { ID }\end{array}$ & Well Label & $\begin{array}{c}\text { Sample } \\
\text { Type }\end{array}$ & Latitude & Longitude & 24K Quad & $\begin{array}{c}\text { Elevation } \\
\text { (ft.) }\end{array}$ & $\begin{array}{c}\text { Total Depth } \\
\text { (ft.) }\end{array}$ \\
\hline 1 & $\mathrm{~W}-802$ & Cuttings & 27.98921 & -82.51695 & GANDY BRIDGE & 30 & 500 \\
\hline 2 & W-1669 & Cuttings & 27.88091 & -82.63834 & SAFETY HARBOR & 3 & 11507 \\
\hline 3 & W-1744 & Cuttings & 27.93447 & -82.77095 & CLEARWATER & 45 & 137 \\
\hline 4 & W-2677 & Cuttings & 27.90675 & -82.30370 & BRANDON & 37 & 443 \\
\hline 5 & W-3118 & Cuttings & 27.76833 & -82.64073 & SAINT PETERSBURG & 32 & 315 \\
\hline 6 & W-3310 & Cuttings & 27.78765 & -82.74174 & SAINT PETERSBURG & 21 & 395 \\
\hline 7 & W-3413 & Cuttings & 27.71796 & -82.73893 & PASS-A-GRILLE BEACH & 5 & 175 \\
\hline 8 & W-6092 & Cuttings & 27.93297 & -82.50736 & GANDY BRIDGE & 18 & 600 \\
\hline 9 & W-7006 & Cuttings & 27.60367 & -82.52686 & PALMETTO & 35 & 380 \\
\hline 10 & W-7337 & Cuttings & 27.59276 & -82.44158 & PARRISH & 34 & 900 \\
\hline 11 & W-9211 & Cuttings & 27.67945 & -82.03389 & DUETTE NE & 137 & 570 \\
\hline 12 & W-9235 & Cuttings & 27.83206 & -82.03466 & KEYSVILLE & 140 & 740 \\
\hline 13 & W-9241 & Cuttings & 27.75881 & -82.01840 & KEYSVILLE & 120 & 704 \\
\hline 14 & W-10577 & Cuttings & 27.95944 & -82.06333 & NICHOLS & 110 & 650 \\
\hline 15 & W-11541 & Core & 27.88872 & -82.48091 & TAMPA & 5 & 400 \\
\hline 16 & W-11570 & Core & 27.64361 & -82.06084 & DUETTE NE & 137 & 462 \\
\hline 17 & W-13515 & Cuttings & 27.73958 & -82.46389 & RUSKIN & 1 & 285 \\
\hline 18 & W-14386 & Cuttings & 27.74083 & -82.14256 & FORT LONESOME & 102 & 925 \\
\hline 19 & W-14778 & Cuttings & 27.84346 & -82.75375 & SEMINOLE & 10 & 260 \\
\hline 20 & W-15379 & Cuttings & 27.92653 & -82.22380 & DOVER & 93 & 820 \\
\hline 21 & W-15380 & Cuttings & 27.93722 & -82.15667 & DOVER & 61 & 900 \\
\hline 22 & W-15389 & Cuttings & 27.99015 & -82.75681 & CLEARWATER & 60 & 200 \\
\hline 23 & W-16181 & Core & 27.91628 & -82.77753 & CLEARWATER & 10 & 801.5 \\
\hline 24 & W-16430 & Cuttings & 27.89871 & -82.70792 & SAFETY HARBOR & 7 & 25 \\
\hline 25 & W-16456 & Core & 27.76200 & -82.25413 & RIVERVIEW & 144 & 1575 \\
\hline 26 & W-16618 & Core & 27.76500 & -82.39389 & GIBSONTON & 13 & 1270 \\
\hline 27 & W-16740 & Core & 27.58948 & -82.25037 & RYE & 129 & 1013 \\
\hline 28 & W-17113 & Core & 27.90055 & -82.37305 & BRANDON & 13 & 470 \\
\hline 29 & W-17600 & Core & 27.61389 & -82.73473 & ANNA MARIA & 7 & 69 \\
\hline 30 & W-18795 & Core & 27.83389 & -82.47305 & GIBSONTON & 5 & 136.5 \\
\hline 31 & W-18816 & Core & 27.87975 & -82.05155 & NICHOLS & 101 & 320 \\
\hline 32 & W-19338 & Core & 27.58112 & -82.43644 & PARRISH & 39 & 1600 \\
\hline 33 & W-19652 & Core & 27.53150 & -82.10333 & DUETTE & 110 & 350 \\
\hline 34 & KT-1 & Core & 27.59139 & -82.08389 & DUETTE & 130 & 67 \\
\hline 35 & $\mathrm{~W}-60$ & Cuttings & 27.98806 & -82.73167 & SAFETY HARBOR & 65 & 846 \\
\hline 36 & W-252 & Cuttings & 27.61589 & -82.73566 & ANNA MARIA & 5 & 991 \\
\hline 37 & W-267 & Cuttings & 27.90225 & -82.14620 & DOVER & 80 & 805 \\
\hline 38 & W-624 & Cuttings & 27.64583 & -82.55417 & COCKROACH BAY & 0 & 270 \\
\hline 39 & W-632 & Cuttings & 27.99940 & -82.01778 & NICHOLS & 135 & 683 \\
\hline 40 & W-688 & Cuttings & 27.97699 & -82.52533 & GANDY BRIDGE & 23 & 221 \\
\hline 41 & W-690 & Cuttings & 27.98092 & -82.51660 & GANDY BRIDGE & 30 & 508 \\
\hline 42 & W-766 & Cuttings & 27.97555 & -82.51507 & GANDY BRIDGE & 30 & 512 \\
\hline 43 & W-953 & Cuttings & 27.95371 & -82.79393 & CLEARWATER & 50 & 296 \\
\hline 44 & W-957 & Cuttings & 27.94373 & -82.46117 & TAMPA & 9 & 350 \\
\hline 45 & W-1005 & Cuttings & 27.80472 & -82.14028 & LITHIA & 98 & 10129 \\
\hline 46 & W-1448 & Cuttings & 27.86856 & -82.11970 & KEYSVILLE & 61 & 820 \\
\hline 47 & W-1523 & Cuttings & 27.87468 & -82.84267 & SEMINOLE & 29 & 258 \\
\hline 48 & W-1604 & Cuttings & 27.92141 & -82.44370 & TAMPA & 3 & 720 \\
\hline 49 & W-1615 & Cuttings & 27.89394 & -82.77077 & CLEARWATER & 15 & 160 \\
\hline 50 & W-1621 & Cuttings & 27.89946 & -82.79723 & CLEARWATER & 67 & 303 \\
\hline 51 & W-1622 & Cuttings & 27.92460 & -82.76279 & CLEARWATER & 16 & 127 \\
\hline 52 & W-1623 & Cuttings & 27.88902 & -82.78879 & CLEARWATER & 35 & 142 \\
\hline 53 & W-1668 & Cuttings & 27.99368 & -82.77527 & CLEARWATER & 20 & 995 \\
\hline 54 & W-1740 & Cuttings & 27.84444 & -82.82127 & SEMINOLE & 27 & 195 \\
\hline 55 & W-1745 & Cuttings & 27.95654 & -82.77573 & CLEARWATER & 62 & 188 \\
\hline
\end{tabular}


FLORIDA GEOLOGICAL SURVEY

\begin{tabular}{|c|c|c|c|c|c|c|c|}
\hline $\begin{array}{l}\text { Map } \\
\text { ID }\end{array}$ & Well Label & $\begin{array}{c}\text { Sample } \\
\text { Type }\end{array}$ & Latitude & Longitude & 24K Quad & $\begin{array}{c}\text { Elevation } \\
\text { (ft.) }\end{array}$ & $\begin{array}{l}\text { Total Depth } \\
\text { (ft.) }\end{array}$ \\
\hline 56 & W-1765 & Cuttings & 27.83014 & -82.24795 & LITHIA & 70 & 140 \\
\hline 57 & W-1823 & Cuttings & 27.52629 & -82.56276 & PALMETTO & 12 & 551 \\
\hline 58 & W-1857 & Cuttings & 27.93013 & -82.21138 & DOVER & 80 & 190 \\
\hline 59 & $\mathrm{~W}-2007$ & Cuttings & 27.99964 & -82.65759 & SAFETY HARBOR & 1 & 1805 \\
\hline 60 & $\mathrm{~W}-2152$ & Cuttings & 27.76669 & -82.21203 & LITHIA & 130 & 816 \\
\hline 61 & $\mathrm{~W}-2178$ & Cuttings & 27.73233 & -82.22191 & FORT LONESOME & 105 & 405 \\
\hline 62 & $\mathrm{~W}-2179$ & Cuttings & 27.76099 & -82.12687 & LITHIA & 120 & 790 \\
\hline 63 & $\mathrm{~W}-2242$ & Cuttings & 27.95332 & -82.28473 & BRANDON & 60 & 101 \\
\hline 64 & $\mathrm{~W}-2283$ & Cuttings & 27.97985 & -82.32054 & BRANDON & 35 & 90 \\
\hline 65 & $\mathrm{~W}-2302$ & Cuttings & 27.97696 & -82.28696 & BRANDON & 61 & 116 \\
\hline 66 & $\mathrm{~W}-2317$ & Cuttings & 27.50670 & -82.45055 & PARRISH & 10 & 620 \\
\hline 67 & $\mathrm{~W}-2324$ & Cuttings & 27.68309 & -82.47426 & RUSKIN & 25 & 640 \\
\hline 68 & $\mathrm{~W}-2352$ & Cuttings & 27.96601 & -82.30962 & BRANDON & 53 & 122 \\
\hline 69 & $\mathrm{~W}-2381$ & Cuttings & 27.89208 & -82.39929 & TAMPA & 5 & 150 \\
\hline 70 & $\mathrm{~W}-2416$ & Cuttings & 27.84078 & -82.14433 & LITHIA & 110 & 495 \\
\hline 71 & $\mathrm{~W}-2437$ & Cuttings & 27.97271 & -82.27599 & BRANDON & 62 & 120 \\
\hline 72 & $\mathrm{~W}-2473$ & Cuttings & 27.95918 & -82.48426 & TAMPA & 35 & 93 \\
\hline 73 & W-2489 & Cuttings & 27.87654 & -82.84891 & CLEARWATER & 0 & 100 \\
\hline 74 & $\mathrm{~W}-2492$ & Cuttings & 27.91947 & -82.52704 & GANDY BRIDGE & 1 & 114 \\
\hline 75 & $\mathrm{~W}-2511$ & Cuttings & 27.73219 & -82.42901 & RUSKIN & 5 & 504 \\
\hline 76 & $\mathrm{~W}-2545$ & Cuttings & 27.72173 & -82.45044 & RUSKIN & 5 & 110 \\
\hline 77 & $\mathrm{~W}-2553$ & Cuttings & 27.52809 & -82.57371 & PALMETTO & 12 & 423 \\
\hline 78 & $\mathrm{~W}-2566$ & Cuttings & 27.81750 & -82.73640 & SAINT PETERSBURG & 15 & 125 \\
\hline 79 & $\mathrm{~W}-2568$ & Cuttings & 27.98415 & -82.27457 & BRANDON & 66 & 182 \\
\hline 80 & $\mathrm{~W}-2574$ & Cuttings & 27.92826 & -82.49322 & TAMPA & 20 & 67 \\
\hline 81 & $\mathrm{~W}-2575$ & Cuttings & 27.85452 & -82.71461 & SAINT PETERSBURG & 11 & 85.5 \\
\hline 82 & $\mathrm{~W}-2586$ & Cuttings & 27.94842 & -82.47308 & TAMPA & 20 & 155 \\
\hline 83 & W-2587 & Cuttings & 27.96583 & -82.54170 & GANDY BRIDGE & 7 & 100.5 \\
\hline 84 & W-2588 & Cuttings & 27.98258 & -82.45914 & TAMPA & 38 & 146 \\
\hline 85 & $\mathrm{~W}-2592$ & Cuttings & 27.97143 & -82.44597 & TAMPA & 45 & 107 \\
\hline 86 & W-2605 & Cuttings & 27.79906 & -82.65056 & SAINT PETERSBURG & 50 & 245 \\
\hline 87 & W-2609 & Cuttings & 27.94378 & -82.49292 & TAMPA & 22 & 59 \\
\hline 88 & $\mathrm{~W}-2659$ & Cuttings & 27.89023 & -82.71951 & SAFETY HARBOR & 15 & 82 \\
\hline 89 & $\mathrm{~W}-2663$ & Cuttings & 27.90055 & -82.72103 & SAFETY HARBOR & 15 & 115 \\
\hline 90 & W-2664 & Cuttings & 27.90395 & -82.50932 & GANDY BRIDGE & 10 & 163 \\
\hline 91 & $\mathrm{~W}-2668$ & Cuttings & 27.77733 & -82.38528 & GIBSONTON & 10 & 275 \\
\hline 92 & W-2681 & Cuttings & 27.96578 & -82.76127 & CLEARWATER & 65 & 289 \\
\hline 93 & $\mathrm{~W}-2689$ & Cuttings & 27.88937 & -82.52696 & GANDY BRIDGE & 5 & 70 \\
\hline 94 & $\mathrm{~W}-2698$ & Cuttings & 27.96370 & -82.77399 & CLEARWATER & 75 & 182 \\
\hline 95 & $\mathrm{~W}-2703$ & Cuttings & 27.87503 & -82.70808 & SAFETY HARBOR & 10 & 134 \\
\hline 96 & $\mathrm{~W}-2704$ & Cuttings & 27.99970 & -82.41821 & TAMPA & 47 & 503 \\
\hline 97 & W-2705 & Cuttings & 27.82491 & -82.66627 & SAINT PETERSBURG & 31 & 180 \\
\hline 98 & $\mathrm{~W}-2710$ & Cuttings & 27.90549 & -82.49348 & TAMPA & 15 & 50 \\
\hline 99 & $\mathrm{~W}-2752$ & Cuttings & 27.77528 & -82.77639 & SEMINOLE & 5 & 150 \\
\hline 100 & $\mathrm{~W}-2760$ & Cuttings & 27.96055 & -82.44305 & TAMPA & 25 & 170 \\
\hline 101 & $\mathrm{~W}-2762$ & Cuttings & 27.72711 & -82.74312 & PASS-A-GRILLE BEACH & 5 & 130 \\
\hline 102 & W-2766 & Cuttings & 27.90500 & -82.73194 & SAFETY HARBOR & 15 & 134 \\
\hline 103 & $\mathrm{~W}-2796$ & Cuttings & 27.70320 & -82.42189 & RUSKIN & 20 & 550 \\
\hline 104 & $\mathrm{~W}-2932$ & Cuttings & 27.99358 & -82.78885 & CLEARWATER & 25 & 184 \\
\hline 105 & W-2942 & Cuttings & 27.94818 & -82.74516 & SAFETY HARBOR & 34 & 284 \\
\hline 106 & W-2949 & Cuttings & 27.90777 & -82.72954 & SAFETY HARBOR & 15 & 123 \\
\hline 107 & W-2954 & Cuttings & 27.99201 & -82.01161 & NICHOLS & 138 & 78 \\
\hline 108 & W-2971 & Cuttings & 27.94813 & -82.73750 & SAFETY HARBOR & 20 & 293 \\
\hline 109 & $\mathrm{~W}-2975$ & Cuttings & 27.69814 & -82.41073 & RUSKIN & 21 & 605 \\
\hline 110 & W-3008 & Cuttings & 27.95167 & -82.75500 & CLEARWATER & 37 & 205 \\
\hline 111 & W-3009 & Cuttings & 27.94415 & -82.80556 & CLEARWATER & 23 & 280 \\
\hline 112 & W-3029 & Cuttings & 27.98967 & -82.45634 & TAMPA & 43 & 183 \\
\hline 113 & W-3067 & Cuttings & 27.82267 & -82.65720 & SAINT PETERSBURG & 19 & 435 \\
\hline 114 & W-3086 & Cuttings & 27.82240 & -82.65662 & SAINT PETERSBURG & 20 & 280 \\
\hline 115 & W-3090 & Cuttings & 27.97336 & -82.78584 & CLEARWATER & 20 & 325 \\
\hline 116 & W-3091 & Cuttings & 27.82267 & -82.65720 & SAINT PETERSBURG & 19 & 330 \\
\hline 117 & W-3113 & Cuttings & 27.85687 & -82.39400 & GIBSONTON & 4 & 793 \\
\hline 118 & W-3114 & Cuttings & 27.93611 & -82.73251 & SAFETY HARBOR & 6 & 110 \\
\hline 119 & W-3117 & Cuttings & 27.76184 & -82.71007 & SAINT PETERSBURG & 23 & 460 \\
\hline
\end{tabular}


OPEN-FILE REPORT 106

\begin{tabular}{|c|c|c|c|c|c|c|c|}
\hline $\begin{array}{l}\text { Map } \\
\text { ID }\end{array}$ & Well Label & $\begin{array}{c}\text { Sample } \\
\text { Type } \\
\end{array}$ & Latitude & Longitude & 24K Quad & $\begin{array}{c}\text { Elevation } \\
\text { (ft.) }\end{array}$ & $\begin{array}{l}\text { Total Depth } \\
\text { (ft.) }\end{array}$ \\
\hline 120 & W-3134 & Cuttings & 27.94950 & -82.76237 & CLEARWATER & 44 & 265 \\
\hline 121 & W-3138 & Cuttings & 27.99172 & -82.73582 & SAFETY HARBOR & 74 & 337 \\
\hline 122 & W-3175 & Cuttings & 27.94071 & -82.51820 & GANDY BRIDGE & 9 & 73 \\
\hline 123 & W-3181 & Cuttings & 27.94141 & -82.27592 & BRANDON & 55 & 335 \\
\hline 124 & W-3209 & Cuttings & 27.57906 & -82.58926 & PALMETTO & 1 & 289 \\
\hline 125 & W-3240 & Cuttings & 27.50456 & -82.51604 & PALMETTO & 3 & 75 \\
\hline 126 & W-3275 & Cuttings & 27.92000 & -82.73000 & SAFETY HARBOR & 15 & 98 \\
\hline 127 & W-3323 & Cuttings & 27.78842 & -82.74215 & SAINT PETERSBURG & 21 & 488 \\
\hline 128 & W-3338 & Cuttings & 27.94444 & -82.48750 & TAMPA & 22 & 225 \\
\hline 129 & W-3369 & Cuttings & 27.90551 & -82.79958 & CLEARWATER & 61 & 120 \\
\hline 130 & $\mathrm{~W}-3370$ & Cuttings & 27.96044 & -82.43815 & TAMPA & 24 & 184 \\
\hline 131 & W-3372 & Cuttings & 27.97363 & -82.78932 & CLEARWATER & 22 & 200 \\
\hline 132 & W-3394 & Cuttings & 27.52444 & -82.52747 & PALMETTO & 10 & 325 \\
\hline 133 & W-3469 & Cuttings & 27.85611 & -82.73695 & SAINT PETERSBURG & 17 & 215 \\
\hline 134 & W-3511 & Cuttings & 27.90139 & -82.73763 & SAFETY HARBOR & 15 & 110 \\
\hline 135 & W-3572 & Cuttings & 27.83822 & -82.76778 & SEMINOLE & 10 & 0 \\
\hline 136 & W-3615 & Cuttings & 27.62949 & -82.66228 & PASS-A-GRILLE BEACH & 0 & 215 \\
\hline 137 & W-3625 & Cuttings & 27.87165 & -82.51069 & PORT TAMPA & 10 & 145 \\
\hline 138 & W-3668 & Cuttings & 27.98811 & -82.49979 & TAMPA & 31 & 205 \\
\hline 139 & W-3682 & Cuttings & 27.95598 & -82.50534 & GANDY BRIDGE & 26 & 143 \\
\hline 140 & W-3759 & Cuttings & 27.81713 & -82.70971 & SAINT PETERSBURG & 23 & 251 \\
\hline 141 & W-3823 & Cuttings & 27.72807 & -82.43298 & RUSKIN & 5 & 175 \\
\hline 142 & W-3854 & Cuttings & 27.95743 & -82.72694 & SAFETY HARBOR & 37 & 120 \\
\hline 143 & W-3860 & Cuttings & 27.82114 & -82.31759 & RIVERVIEW & 83 & 323 \\
\hline 144 & W-3953 & Cuttings & 27.90280 & -82.73138 & SAFETY HARBOR & 15 & 38 \\
\hline 145 & W-3966 & Cuttings & 27.94382 & -82.50671 & GANDY BRIDGE & 22 & 427 \\
\hline 146 & W-3969 & Cuttings & 27.94498 & -82.35540 & BRANDON & 28 & 80 \\
\hline 147 & W-3971 & Cuttings & 27.89287 & -82.83057 & CLEARWATER & 20 & 130 \\
\hline 148 & W-3972 & Cuttings & 27.91763 & -82.78682 & CLEARWATER & 50 & 190 \\
\hline 149 & W-3973 & Cuttings & 27.87377 & -82.74854 & SAINT PETERSBURG & 19 & 202 \\
\hline 150 & W-3988 & Cuttings & 27.99576 & -82.44216 & TAMPA & 55 & 324 \\
\hline 151 & W-3989 & Cuttings & 27.83444 & -82.72972 & SAINT PETERSBURG & 15 & 77.5 \\
\hline 152 & W-3996 & Cuttings & 27.99585 & -82.38120 & TAMPA & 34 & 338 \\
\hline 153 & W-4016 & Cuttings & 27.85610 & -82.73000 & SAINT PETERSBURG & 15 & 112 \\
\hline 154 & W-4084 & Cuttings & 27.93186 & -82.21055 & DOVER & 77 & 450 \\
\hline 155 & W-4159 & Cuttings & 27.95881 & -82.52640 & GANDY BRIDGE & 14 & 175 \\
\hline 156 & W-4282 & Cuttings & 27.96661 & -82.37830 & TAMPA & 30 & 556 \\
\hline 157 & W-4411 & Cuttings & 27.97816 & -82.44273 & TAMPA & 50 & 140 \\
\hline 158 & W-4508 & Cuttings & 27.94400 & -82.47756 & TAMPA & 20 & 114 \\
\hline 159 & W-4648 & Cuttings & 27.83644 & -82.65504 & SAINT PETERSBURG & 5 & 187 \\
\hline 160 & W-4687 & Cuttings & 27.96796 & -82.46311 & TAMPA & 40 & 228 \\
\hline 161 & $\mathrm{~W}-4702$ & Cuttings & 27.90195 & -82.52694 & GANDY BRIDGE & 4 & 265 \\
\hline 162 & W-4731 & Cuttings & 27.92996 & -82.31049 & BRANDON & 30 & 269 \\
\hline 163 & W-4802 & Cuttings & 27.85667 & -82.32694 & RIVERVIEW & 40 & 337 \\
\hline 164 & W-4831 & Cuttings & 27.98156 & -82.33488 & BRANDON & 50 & 305 \\
\hline 165 & W-5067 & Cuttings & 27.88656 & -82.69172 & SAFETY HARBOR & 11 & 144 \\
\hline 166 & W-5078 & Cuttings & 27.83013 & -82.24795 & LITHIA & 70 & 346 \\
\hline 167 & W-5209 & Cuttings & 27.94442 & -82.39361 & TAMPA & 6 & 80 \\
\hline 168 & W-5254 & Cuttings & 27.96498 & -82.23840 & DOVER & 84 & 330 \\
\hline 169 & W-5396 & Cuttings & 27.94926 & -82.45469 & TAMPA & 20 & 225 \\
\hline 170 & W-5414 & Cuttings & 27.86270 & -82.54149 & PORT TAMPA & 5 & 581 \\
\hline 171 & W-5457 & Cuttings & 27.90962 & -82.38445 & TAMPA & 10 & 94 \\
\hline 172 & W-5498 & Cuttings & 27.67833 & -82.39421 & RUSKIN & 13 & 493 \\
\hline 173 & W-5522 & Cuttings & 27.92372 & -82.50153 & GANDY BRIDGE & 20 & 76 \\
\hline 174 & W-5524 & Cuttings & 27.89899 & -82.51659 & GANDY BRIDGE & 10 & 140 \\
\hline 175 & W-5577 & Cuttings & 27.89389 & -82.69210 & SAFETY HARBOR & 10 & 160 \\
\hline 176 & W-5596 & Cuttings & 27.54611 & -82.50756 & PALMETTO & 30 & 180 \\
\hline 177 & W-5662 & Cuttings & 27.84918 & -82.37315 & RIVERVIEW & 12 & 150 \\
\hline 178 & W-5678 & Cuttings & 27.72595 & -82.03335 & DUETTE NE & 113 & 500 \\
\hline 179 & W-5683 & Cuttings & 27.97916 & -82.45156 & TAMPA & 50 & 150 \\
\hline 180 & W-5718 & Cuttings & 27.95115 & -82.33521 & BRANDON & 40 & 182 \\
\hline 181 & W-5751 & Cuttings & 27.87181 & -82.71281 & SAINT PETERSBURG & 15 & 104 \\
\hline 182 & W-5800 & Cuttings & 27.98259 & -82.30354 & BRANDON & 65 & 615 \\
\hline 183 & W-5945 & Cuttings & 27.70894 & -82.36467 & WIMAUMA & 30 & 257 \\
\hline
\end{tabular}


FLORIDA GEOLOGICAL SURVEY

\begin{tabular}{|c|c|c|c|c|c|c|c|}
\hline $\begin{array}{c}\text { Map } \\
\text { ID }\end{array}$ & Well Label & $\begin{array}{c}\text { Sample } \\
\text { Type }\end{array}$ & Latitude & Longitude & 24K Quad & $\begin{array}{l}\text { Elevation } \\
\text { (ft.) }\end{array}$ & $\begin{array}{l}\text { Total Depth } \\
\text { (ft.) }\end{array}$ \\
\hline 184 & W-5957 & Cuttings & 27.77225 & -82.14925 & LITHIA & 116 & 926 \\
\hline 185 & W-6140 & Cuttings & 27.98840 & -82.08298 & NICHOLS & 135 & 721 \\
\hline 186 & W-6255 & Cuttings & 27.87143 & -82.29424 & RIVERVIEW & 24 & 176 \\
\hline 187 & W-6324 & Cuttings & 27.89153 & -82.32890 & BRANDON & 37 & 84 \\
\hline 188 & W-6330 & Cuttings & 27.53333 & -82.51389 & PALMETTO & 15 & 255 \\
\hline 189 & W-6438 & Cuttings & 27.63750 & -82.54028 & COCKROACH BAY & 10 & 115 \\
\hline 190 & W-6439 & Cuttings & 27.58226 & -82.59943 & PALMETTO & 4 & 150 \\
\hline 191 & W-6584 & Cuttings & 27.59278 & -82.21111 & KEENTOWN & 118 & 1162 \\
\hline 192 & W-6623 & Cuttings & 27.60092 & -82.45837 & PARRISH & 29 & 928 \\
\hline 193 & W-6688 & Cuttings & 27.61195 & -82.52730 & PALMETTO & 28 & 205 \\
\hline 194 & W-6698 & Cuttings & 27.51917 & -82.53744 & PALMETTO & 5 & 50 \\
\hline 195 & W-6708 & Cuttings & 27.57917 & -82.40977 & PARRISH & 32 & 31 \\
\hline 196 & W-6813 & Cuttings & 27.56528 & -82.53944 & PALMETTO & 19 & 90 \\
\hline 197 & W-6816 & Cuttings & 27.51739 & -82.57943 & PALMETTO & 10 & 100 \\
\hline 198 & W-6828 & Cuttings & 27.54917 & -82.55611 & PALMETTO & 20 & 130 \\
\hline 199 & W-6896 & Cuttings & 27.51912 & -82.58501 & PALMETTO & 8 & 80 \\
\hline 200 & W-6898 & Cuttings & 27.53137 & -82.49698 & PARRISH & 5 & 350 \\
\hline 201 & W-6953 & Cuttings & 27.62222 & -82.47500 & PARRISH & 24 & 600 \\
\hline 202 & W-6972 & Cuttings & 27.63889 & -82.55417 & COCKROACH BAY & 5 & 585 \\
\hline 203 & W-6973 & Cuttings & 27.60750 & -82.48000 & PARRISH & 30 & 1057 \\
\hline 204 & W-6978 & Cuttings & 27.99596 & -82.23414 & DOVER & 98 & 465 \\
\hline 205 & W-6982 & Cuttings & 27.90215 & -82.41185 & TAMPA & 0 & 150 \\
\hline 206 & W-6983 & Cuttings & 27.95917 & -82.34390 & BRANDON & 30 & 165 \\
\hline 207 & W-6988 & Cuttings & 27.53820 & -82.47224 & PARRISH & 20 & 44 \\
\hline 208 & W-6992 & Cuttings & 27.51725 & -82.53470 & PALMETTO & 5 & 100 \\
\hline 209 & W-7001 & Cuttings & 27.60318 & -82.51010 & PALMETTO & 30 & 400 \\
\hline 210 & W-7035 & Cuttings & 27.97729 & -82.42301 & TAMPA & 54 & 250 \\
\hline 211 & W-7052 & Cuttings & 27.55106 & -82.44754 & PARRISH & 34 & 628 \\
\hline 212 & W-7189 & Cuttings & 27.51404 & -82.71228 & ANNA MARIA & 0 & 360 \\
\hline 213 & W-7191 & Cuttings & 27.50064 & -82.42957 & PARRISH & 15 & 87 \\
\hline 214 & W-7261 & Cuttings & 27.52222 & -82.60500 & PALMETTO & 4 & 127 \\
\hline 215 & W-7282 & Cuttings & 27.54011 & -82.52807 & PALMETTO & 20 & 230 \\
\hline 216 & W-7330 & Cuttings & 27.51472 & -82.42583 & PARRISH & 0 & 50 \\
\hline 217 & W-7385 & Cuttings & 27.70982 & -82.30104 & WIMAUMA & 100 & 300 \\
\hline 218 & W-7494 & Cuttings & 27.52498 & -82.71862 & ANNA MARIA & 0 & 375 \\
\hline 219 & W-7495 & Cuttings & 27.57086 & -82.14012 & KEENTOWN & 108 & 500 \\
\hline 220 & W-7497 & Cuttings & 27.59444 & -82.40833 & PARRISH & 26 & 600 \\
\hline 221 & W-7501 & Cuttings & 27.56389 & -82.49111 & PARRISH & 30 & 900 \\
\hline 222 & W-7572 & Cuttings & 27.86421 & -82.39930 & GIBSONTON & 4 & 1075 \\
\hline 223 & W-7672 & Cuttings & 27.85750 & -82.49445 & GIBSONTON & 8 & 1000 \\
\hline 224 & W-7690 & Cuttings & 27.93472 & -82.35455 & BRANDON & 21 & 350 \\
\hline 225 & W-7815 & Cuttings & 27.59361 & -82.49084 & PARRISH & 25 & 612 \\
\hline 226 & W-7816 & Cuttings & 27.55195 & -82.53989 & PALMETTO & 20 & 340 \\
\hline 227 & W-7979 & Cuttings & 27.51639 & -82.65222 & ANNA MARIA & 16 & 120 \\
\hline 228 & W-7982 & Cuttings & 27.50556 & -82.39278 & PARRISH & 20 & 515 \\
\hline 229 & W-7986 & Cuttings & 27.96828 & -82.33017 & BRANDON & 35 & 140 \\
\hline 230 & W-8029 & Cuttings & 27.56196 & -82.43440 & PARRISH & 45 & 412 \\
\hline 231 & W-8030 & Cuttings & 27.63463 & -82.54131 & COCKROACH BAY & 10 & 588 \\
\hline 232 & W-8039 & Cuttings & 27.91521 & -82.31045 & BRANDON & 35 & 190 \\
\hline 233 & W-8144 & Cuttings & 27.54971 & -82.40922 & PARRISH & 25 & 126 \\
\hline 234 & W-8145 & Cuttings & 27.52083 & -82.42528 & PARRISH & 0 & 90 \\
\hline 235 & W-8147 & Cuttings & 27.55207 & -82.09203 & DUETTE & 110 & 237 \\
\hline 236 & W-8148 & Cuttings & 27.62278 & -82.47972 & PARRISH & 25 & 185 \\
\hline 237 & W-8157 & Cuttings & 27.60889 & -82.46101 & PARRISH & 25 & 940 \\
\hline 238 & W-8226 & Cuttings & 27.58000 & -82.50555 & PALMETTO & 15 & 365 \\
\hline 239 & W-8311 & Cuttings & 27.55503 & -82.47295 & PARRISH & 30 & 605 \\
\hline 240 & W-8313 & Cuttings & 27.56083 & -82.56722 & PALMETTO & 5 & 360 \\
\hline 241 & W-8438 & Cuttings & 27.56738 & -82.53101 & PALMETTO & 28 & 185 \\
\hline 242 & W-8440 & Cuttings & 27.53583 & -82.50756 & PALMETTO & 20 & 110 \\
\hline 243 & W-8573 & Cuttings & 27.95913 & -82.42662 & TAMPA & 12 & 503 \\
\hline 244 & W-8707 & Cuttings & 27.82087 & -82.32963 & RIVERVIEW & 60 & 600 \\
\hline 245 & W-8712 & Cuttings & 27.71250 & -82.37833 & RUSKIN & 35 & 600 \\
\hline 246 & W-8714 & Cuttings & 27.71276 & -82.39413 & RUSKIN & 36 & 600 \\
\hline 247 & W-8719 & Cuttings & 27.60833 & -82.40139 & PARRISH & 27 & 785 \\
\hline
\end{tabular}


OPEN-FILE REPORT 106

\begin{tabular}{|c|c|c|c|c|c|c|c|}
\hline $\begin{array}{c}\text { Map } \\
\text { ID }\end{array}$ & Well Label & $\begin{array}{c}\text { Sample } \\
\text { Type }\end{array}$ & Latitude & Longitude & 24K Quad & $\begin{array}{l}\text { Elevation } \\
\text { (ft.) }\end{array}$ & $\begin{array}{l}\text { Total Depth } \\
\text { (ft.) }\end{array}$ \\
\hline 248 & W-8787 & Cuttings & 27.58369 & -82.20335 & KEENTOWN & 115 & 210 \\
\hline 249 & W-8797 & Cuttings & 27.64472 & -82.14528 & FORT LONESOME & 130 & 975 \\
\hline 250 & W-8800 & Cuttings & 27.62192 & -82.53996 & PALMETTO & 10 & 150 \\
\hline 251 & W-8802 & Cuttings & 27.61352 & -82.22755 & KEENTOWN & 108 & 730 \\
\hline 252 & W-9019 & Cuttings & 27.70810 & -82.05914 & DUETTE NE & 135 & 335 \\
\hline 253 & W-9020 & Cuttings & 27.82479 & -82.09205 & KEYSVILLE & 96 & 730 \\
\hline 254 & W-9021 & Cuttings & 27.85393 & -82.10011 & KEYSVILLE & 64 & 710 \\
\hline 255 & W-9022 & Cuttings & 27.84620 & -82.17456 & LITHIA & 110 & 740 \\
\hline 256 & W-9025 & Cuttings & 27.79564 & -82.06755 & KEYSVILLE & 148 & 736 \\
\hline 257 & W-9028 & Core & 27.85387 & -82.06763 & KEYSVILLE & 128 & 490 \\
\hline 258 & W-9029 & Cuttings & 27.88778 & -82.17268 & DOVER & 74 & 482 \\
\hline 259 & W-9030 & Cuttings & 27.76040 & -82.16055 & LITHIA & 103 & 750 \\
\hline 260 & W-9035 & Cuttings & 27.68237 & -82.21277 & FORT LONESOME & 60 & 470 \\
\hline 261 & W-9037 & Cuttings & 27.77639 & -82.11293 & KEYSVILLE & 130 & 580 \\
\hline 262 & W-9038 & Core & 27.78833 & -82.10022 & KEYSVILLE & 130 & 700 \\
\hline 263 & W-9039 & Cuttings & 27.88305 & -82.20750 & DOVER & 40 & 480 \\
\hline 264 & W-9040 & Cuttings & 27.82293 & -82.24257 & LITHIA & 80 & 425 \\
\hline 265 & W-9041 & Cuttings & 27.82457 & -82.14990 & LITHIA & 100 & 610 \\
\hline 266 & W-9043 & Cuttings & 27.89028 & -82.10031 & NICHOLS & 90 & 560 \\
\hline 267 & W-9081 & Cuttings & 27.55157 & -82.01060 & DUETTE & 115 & 1030 \\
\hline 268 & W-9220 & Cuttings & 27.73699 & -82.00204 & DUETTE NE & 132 & 715 \\
\hline 269 & W-9222 & Cuttings & 27.87045 & -82.02045 & KEYSVILLE & 121 & 345 \\
\hline 270 & W-9280 & Cuttings & 27.59250 & -82.11444 & DUETTE & 125 & 989 \\
\hline 271 & W-9282 & Cuttings & 27.53333 & -82.08334 & DUETTE & 113 & 850 \\
\hline 272 & W-9283 & Cuttings & 27.64437 & -82.11577 & DUETTE NE & 126 & 1027 \\
\hline 273 & W-10382 & Cuttings & 27.55606 & -82.40297 & PARRISH & 31 & 265 \\
\hline 274 & W-10410 & Core & 27.97779 & -82.75883 & CLEARWATER & 70 & 77 \\
\hline 275 & W-10411 & Core & 27.98448 & -82.70673 & SAFETY HARBOR & 18 & 62 \\
\hline 276 & W-10497 & Cuttings & 27.69917 & -82.16250 & FORT LONESOME & 105 & 222 \\
\hline 277 & W-10556 & Cuttings & 27.55585 & -82.41666 & PARRISH & 35 & 100 \\
\hline 278 & W-10563 & Cuttings & 27.60695 & -82.27639 & RYE & 110 & 1025 \\
\hline 279 & W-10575 & Cuttings & 27.98197 & -82.34763 & BRANDON & 35 & 250 \\
\hline 280 & W-10628 & Cuttings & 27.66747 & -82.36172 & WIMAUMA & 30 & 470 \\
\hline 281 & W-10684 & Cuttings & 27.98706 & -82.31699 & BRANDON & 46 & 96 \\
\hline 282 & W-10725 & Cuttings & 27.89448 & -82.23067 & DOVER & 50 & 150 \\
\hline 283 & W-10741 & Cuttings & 27.97499 & -82.25068 & BRANDON & 54 & 470 \\
\hline 284 & W-10900 & Cuttings & 27.93473 & -82.22800 & DOVER & 75 & 280 \\
\hline 285 & W-10951 & Cuttings & 27.95966 & -82.03113 & NICHOLS & 117 & 150 \\
\hline 286 & W-10990 & Cuttings & 27.85750 & -82.03111 & KEYSVILLE & 130 & 1208 \\
\hline 287 & W-11011 & Cuttings & 27.54354 & -82.46109 & PARRISH & 35 & 255 \\
\hline 288 & W-11019 & Cuttings & 27.62365 & -82.52787 & PALMETTO & 16 & 150 \\
\hline 289 & W-11026 & Cuttings & 27.54289 & -82.47736 & PARRISH & 30 & 167 \\
\hline 290 & W-11029 & Cuttings & 27.52120 & -82.51438 & PALMETTO & 5 & 185 \\
\hline 291 & W-11119 & Cuttings & 27.96141 & -82.73344 & SAFETY HARBOR & 60 & 240 \\
\hline 292 & W-11196 & Cuttings & 27.72177 & -82.38525 & RUSKIN & 45 & 210 \\
\hline 293 & W-11240 & Cuttings & 27.62747 & -82.53824 & COCKROACH BAY & 10 & 850 \\
\hline 294 & W-11275 & Cuttings & 27.59276 & -82.54145 & PALMETTO & 17 & 200 \\
\hline 295 & W-11278 & Cuttings & 27.63782 & -82.44102 & RUSKIN & 30 & 75 \\
\hline 296 & W-11338 & Cuttings & 27.98529 & -82.34953 & BRANDON & 31 & 332 \\
\hline 297 & W-11432 & Cuttings & 27.91836 & -82.29787 & BRANDON & 44 & 351 \\
\hline 298 & W-11488 & Cuttings & 27.97954 & -82.39521 & TAMPA & 49 & 140 \\
\hline 299 & W-11509 & Cuttings & 27.98326 & -82.38425 & TAMPA & 35 & 180 \\
\hline 300 & W-11531 & Core & 27.92808 & -82.28620 & BRANDON & 39 & 160 \\
\hline 301 & W-11612 & Cuttings & 27.90947 & -82.01382 & NICHOLS & 100 & 106 \\
\hline 302 & W-11615 & Cuttings & 27.94582 & -82.03112 & NICHOLS & 120 & 365 \\
\hline 303 & W-11706 & Cuttings & 27.53391 & -82.61322 & PALMETTO & 0 & 50 \\
\hline 304 & W-11708 & Cuttings & 27.52037 & -82.37611 & PARRISH & 10 & 175 \\
\hline 305 & W-11710 & Cuttings & 27.50761 & -82.36559 & RYE & 11 & 110 \\
\hline 306 & W-11712 & Cuttings & 27.54989 & -82.47475 & PARRISH & 32 & 445 \\
\hline 307 & W-11749 & Cuttings & 27.57964 & -82.56913 & PALMETTO & 5 & 330 \\
\hline 308 & W-11780 & Cuttings & 27.75582 & -82.31055 & RIVERVIEW & 72 & 500 \\
\hline 309 & W-11956 & Cuttings & 27.68601 & -82.49287 & RUSKIN & 5 & 354 \\
\hline 310 & W-12144 & Cuttings & 27.50381 & -82.64529 & ANNA MARIA & 7 & 115 \\
\hline 311 & W-12198 & Cuttings & 27.70084 & -82.46122 & RUSKIN & 13 & 206 \\
\hline
\end{tabular}


FLORIDA GEOLOGICAL SURVEY

\begin{tabular}{|c|c|c|c|c|c|c|c|}
\hline $\begin{array}{c}\text { Map } \\
\text { ID }\end{array}$ & Well Label & $\begin{array}{l}\text { Sample } \\
\text { Type }\end{array}$ & Latitude & Longitude & 24K Quad & $\begin{array}{l}\text { Elevation } \\
\text { (ft.) }\end{array}$ & $\begin{array}{l}\text { Total Depth } \\
\text { (ft.) }\end{array}$ \\
\hline 312 & W-12201 & Cuttings & 27.82825 & -82.76238 & SEMINOLE & 7 & 170 \\
\hline 313 & W-12205 & Cuttings & 27.85200 & -82.14581 & LITHIA & 107 & 133 \\
\hline 314 & W-12207 & Cuttings & 27.82890 & -82.73808 & SAINT PETERSBURG & 13 & 180 \\
\hline 315 & W-12252 & Cuttings & 27.66765 & -82.44347 & RUSKIN & 20 & 425 \\
\hline 316 & W-12285 & Cuttings & 27.89700 & -82.76115 & CLEARWATER & 19 & 170 \\
\hline 317 & W-12288 & Cuttings & 27.51218 & -82.68291 & ANNA MARIA & 0 & 410 \\
\hline 318 & W-12298 & Cuttings & 27.71388 & -82.33662 & WIMAUMA & 65 & 270 \\
\hline 319 & W-12299 & Cuttings & 27.68752 & -82.47029 & RUSKIN & 22 & 220 \\
\hline 320 & W-12327 & Cuttings & 27.64311 & -82.14192 & FORT LONESOME & 130 & 830 \\
\hline 321 & W-12330 & Cuttings & 27.57615 & -82.19120 & KEENTOWN & 112 & 1030 \\
\hline 322 & W-12568 & Cuttings & 27.86493 & -82.22794 & LITHIA & 40 & 192 \\
\hline 323 & W-12627 & Cuttings & 27.68443 & -82.45874 & RUSKIN & 20 & 400 \\
\hline 324 & W-12744 & Cuttings & 27.84948 & -82.17409 & LITHIA & 106 & 130 \\
\hline 325 & W-12784 & Cuttings & 27.63798 & -82.34251 & WIMAUMA & 50 & 500 \\
\hline 326 & W-12833 & Cuttings & 27.71356 & -82.31473 & WIMAUMA & 95 & 270 \\
\hline 327 & W-13098 & Cuttings & 27.89391 & -82.28675 & BRANDON & 30 & 380 \\
\hline 328 & W-13099 & Cuttings & 27.74278 & -82.33778 & WIMAUMA & 52 & 500 \\
\hline 329 & W-13100 & Cuttings & 27.88750 & -82.26722 & BRANDON & 55 & 750 \\
\hline 330 & W-13101 & Cuttings & 27.72110 & -82.33746 & WIMAUMA & 66 & 500 \\
\hline 331 & W-13179 & Cuttings & 27.91545 & -82.39829 & TAMPA & 8 & 152 \\
\hline 332 & W-13183 & Cuttings & 27.99374 & -82.20766 & DOVER & 124 & 300 \\
\hline 333 & W-13191 & Cuttings & 27.91275 & -82.02381 & NICHOLS & 100 & 480 \\
\hline 334 & W-13285 & Cuttings & 27.56305 & -82.27749 & RYE & 98 & 825 \\
\hline 335 & W-13288 & Cuttings & 27.79891 & -82.27688 & RIVERVIEW & 90 & 400 \\
\hline 336 & W-13331 & Cuttings & 27.72078 & -82.06937 & DUETTE NE & 105 & 165 \\
\hline 337 & W-13333 & Core & 27.51667 & -82.00139 & DUETTE & 110 & 198 \\
\hline 338 & W-13337 & Cuttings & 27.68692 & -82.32835 & WIMAUMA & 57 & 300 \\
\hline 339 & W-13354 & Cuttings & 27.59417 & -82.53333 & PALMETTO & 30 & 56 \\
\hline 340 & W-13413 & Cuttings & 27.56969 & -82.37724 & PARRISH & 25 & 300 \\
\hline 341 & W-13442 & Cuttings & 27.71670 & -82.68179 & PASS-A-GRILLE BEACH & 5 & 650 \\
\hline 342 & W-13443 & Cuttings & 27.71742 & -82.68230 & PASS-A-GRILLE BEACH & 5 & 1120 \\
\hline 343 & W-13499 & Cuttings & 27.53272 & -82.52801 & PALMETTO & 20 & 110 \\
\hline 344 & W-13510 & Cuttings & 27.75583 & -82.06416 & KEYSVILLE & 100 & 910 \\
\hline 345 & W-13556 & Cuttings & 27.82684 & -82.61710 & PORT TAMPA & 4 & 150 \\
\hline 346 & W-13571 & Cuttings & 27.96030 & -82.27203 & BRANDON & 75 & 370 \\
\hline 347 & W-13580 & Cuttings & 27.95271 & -82.11510 & NICHOLS & 120 & 247 \\
\hline 348 & W-13610 & Cuttings & 27.82843 & -82.61959 & PORT TAMPA & 5 & 1211 \\
\hline 349 & W-13636 & Core & 27.78238 & -82.16875 & LITHIA & 119 & 21 \\
\hline 350 & W-13637 & Core & 27.99422 & -82.08659 & NICHOLS & 142 & 20 \\
\hline 351 & W-13644 & Core & 27.92461 & -82.16428 & DOVER & 66 & 20 \\
\hline 352 & W-13652 & Core & 27.79000 & -82.00000 & BRADLEY JUNCTION & 120 & 20 \\
\hline 353 & W-13662 & Core & 27.78805 & -82.20773 & LITHIA & 94 & 21 \\
\hline 354 & W-13667 & Core & 27.92826 & -82.20028 & DOVER & 57 & 20 \\
\hline 355 & W-13669 & Core & 27.78154 & -82.21445 & LITHIA & 101 & 20 \\
\hline 356 & W-13838 & Cuttings & 27.90868 & -82.16113 & DOVER & 70 & 1000 \\
\hline 357 & W-13935 & Cuttings & 27.71893 & -82.40589 & RUSKIN & 24 & 170 \\
\hline 358 & W-13960 & Cuttings & 27.62374 & -82.50761 & PALMETTO & 33 & 640 \\
\hline 359 & W-13969 & Cuttings & 27.79651 & -82.33621 & RIVERVIEW & 55 & 125 \\
\hline 360 & W-14055 & Cuttings & 27.62465 & -82.15334 & KEENTOWN & 125 & 250 \\
\hline 361 & W-14061 & Cuttings & 27.92661 & -82.24072 & DOVER & 105 & 500 \\
\hline 362 & W-14064 & Cuttings & 27.91549 & -82.24445 & DOVER & 90 & 430 \\
\hline 363 & W-14076 & Cuttings & 27.71383 & -82.29812 & WIMAUMA & 102 & 195 \\
\hline 364 & W-14113 & Cuttings & 27.95534 & -82.33335 & BRANDON & 39 & 100 \\
\hline 365 & W-14171 & Cuttings & 27.93957 & -82.23840 & DOVER & 52 & 160 \\
\hline 366 & W-14191 & Cuttings & 27.94282 & -82.17651 & DOVER & 80 & 194 \\
\hline 367 & W-14273 & Cuttings & 27.94791 & -82.25644 & BRANDON & 55 & 462 \\
\hline 368 & W-14274 & Cuttings & 27.97002 & -82.27093 & BRANDON & 67 & 355 \\
\hline 369 & W-14275 & Cuttings & 27.91092 & -82.27341 & BRANDON & 68 & 335 \\
\hline 370 & W-14305 & Cuttings & 27.99501 & -82.33275 & BRANDON & 54 & 105 \\
\hline 371 & W-14335 & Cuttings & 27.96017 & -82.70485 & SAFETY HARBOR & 0 & 1332 \\
\hline 372 & W-14567 & Cuttings & 27.63059 & -82.52763 & COCKROACH BAY & 20 & 160 \\
\hline 373 & W-14571 & Cuttings & 27.58078 & -82.19038 & KEENTOWN & 108 & 670 \\
\hline 374 & W-14663 & Cuttings & 27.93658 & -82.00601 & NICHOLS & 120 & 760 \\
\hline 375 & W-14668 & Cuttings & 27.95172 & -82.36996 & BRANDON & 3 & 589 \\
\hline
\end{tabular}


OPEN-FILE REPORT 106

\begin{tabular}{|c|c|c|c|c|c|c|c|}
\hline $\begin{array}{c}\text { Map } \\
\text { ID }\end{array}$ & Well Label & $\begin{array}{c}\text { Sample } \\
\text { Type }\end{array}$ & Latitude & Longitude & 24K Quad & $\begin{array}{c}\text { Elevation } \\
\text { (ft.) }\end{array}$ & $\begin{array}{c}\text { Total Depth } \\
\text { (ft.) }\end{array}$ \\
\hline 376 & W-14739 & Cuttings & 27.87171 & -82.14568 & LITHIA & 36 & 400 \\
\hline 377 & W-14779 & Cuttings & 27.84331 & -82.75373 & SEMINOLE & 10 & 560 \\
\hline 378 & W-14831 & Cuttings & 27.71538 & -82.14114 & FORT LONESOME & 0 & 520 \\
\hline 379 & W-14843 & Cuttings & 27.65269 & -82.04491 & DUETTE NE & 135 & 410 \\
\hline 380 & W-14845 & Cuttings & 27.84320 & -82.75374 & SEMINOLE & 10 & 1090 \\
\hline 381 & W-14847 & Cuttings & 27.68222 & -82.01417 & DUETTE NE & 130 & 180 \\
\hline 382 & W-14888 & Cuttings & 27.76308 & -82.25370 & RIVERVIEW & 145 & 620 \\
\hline 383 & W-14896 & Cuttings & 27.87919 & -82.84344 & CLEARWATER & 11 & 1000 \\
\hline 384 & W-14899 & Cuttings & 27.65650 & -82.09428 & DUETTE NE & 132 & 80 \\
\hline 385 & W-14902 & Cuttings & 27.65345 & -82.09563 & DUETTE NE & 140 & 1140 \\
\hline 386 & W-14905 & Cuttings & 27.64965 & -82.09399 & DUETTE NE & 132 & 1240 \\
\hline 387 & W-14999 & Cuttings & 27.92299 & -82.36301 & BRANDON & 20 & 315 \\
\hline 388 & W-15007 & Cuttings & 27.93773 & -82.24458 & DOVER & 40 & 820 \\
\hline 389 & W-15104 & Cuttings & 27.89227 & -82.81992 & CLEARWATER & 34 & 901 \\
\hline 390 & W-15156 & Cuttings & 27.93008 & -82.16222 & DOVER & 66 & 865 \\
\hline 391 & W-15161 & Core & 27.95014 & -82.38490 & TAMPA & 2 & 598.5 \\
\hline 392 & W-15280 & Cuttings & 27.64750 & -82.46639 & RUSKIN & 20 & 1060 \\
\hline 393 & W-15283 & Cuttings & 27.64756 & -82.45947 & RUSKIN & 23 & 205 \\
\hline 394 & W-15328 & Cuttings & 27.97028 & -82.21472 & DOVER & 80 & 648 \\
\hline 395 & W-15381 & Cuttings & 27.99542 & -82.75259 & CLEARWATER & 65 & 240 \\
\hline 396 & W-15384 & Cuttings & 27.99630 & -82.72642 & SAFETY HARBOR & 70 & 275 \\
\hline 397 & W-15386 & Cuttings & 27.97709 & -82.74825 & SAFETY HARBOR & 65 & 200 \\
\hline 398 & W-15388 & Cuttings & 27.96981 & -82.74866 & SAFETY HARBOR & 70 & 220 \\
\hline 399 & W-15517 & Core & 27.51009 & -82.25981 & RYE & 93 & 150 \\
\hline 400 & W-15518 & Core & 27.53223 & -82.22362 & KEENTOWN & 122 & 193 \\
\hline 401 & W-15642 & Cuttings & 27.74103 & -82.42284 & RUSKIN & 5 & 785 \\
\hline 402 & W-15677 & Core & 27.50055 & -82.45277 & PARRISH & 15 & 100 \\
\hline 403 & W-15679 & Core & 27.50055 & -82.45277 & PARRISH & 15 & 31 \\
\hline 404 & W-16004 & Cuttings & 27.85389 & -82.21528 & LITHIA & 66 & 1200 \\
\hline 405 & W-16197 & Core & 27.90901 & -82.72035 & SAFETY HARBOR & 15 & 677.5 \\
\hline 406 & W-16260 & Core & 27.60056 & -82.52701 & PALMETTO & 35 & 150 \\
\hline 407 & W-16268 & Core & 27.71111 & -82.26167 & WIMAUMA & 80 & 101.5 \\
\hline 408 & W-16271 & Core & 27.60028 & -82.29807 & RYE & 72 & 100 \\
\hline 409 & W-16429 & Cuttings & 27.89076 & -82.67585 & SAFETY HARBOR & 5 & 35 \\
\hline 410 & W-16431 & Cuttings & 27.88278 & -82.71389 & SAFETY HARBOR & 3 & 25 \\
\hline 411 & W-16432 & Cuttings & 27.87449 & -82.70383 & SAINT PETERSBURG & 11 & 25 \\
\hline 412 & W-16433 & Cuttings & 27.86826 & -82.73455 & SAINT PETERSBURG & 11 & 0 \\
\hline 413 & W-16466 & Cuttings & 27.99722 & -82.51500 & GANDY BRIDGE & 26 & 60 \\
\hline 414 & W-16576 & Core & 27.99055 & -82.20944 & DOVER & 110 & 839 \\
\hline 415 & W-16577 & Core & 27.96639 & -82.14833 & DOVER & 105 & 299 \\
\hline 416 & W-16838 & Core & 27.59365 & -82.42639 & PARRISH & 40 & 38 \\
\hline 417 & W-17063 & Cuttings & 27.63778 & -82.32714 & WIMAUMA & 33 & 700 \\
\hline 418 & W-17073 & Cuttings & 27.82500 & -82.74361 & SAINT PETERSBURG & 3 & 550 \\
\hline 419 & W-17084 & Cuttings & 27.77194 & -82.71445 & SAINT PETERSBURG & 17 & 3200 \\
\hline 420 & W-17555 & Cuttings & 27.76444 & -82.36806 & RIVERVIEW & 44 & 885 \\
\hline 421 & W-17578 & Core & 27.87944 & -82.80611 & CLEARWATER & 54 & 545 \\
\hline 422 & W-17579 & Cuttings & 27.77833 & -82.40556 & GIBSONTON & 3 & 800 \\
\hline 423 & W-17599 & Core & 27.64417 & -82.73917 & PASS-A-GRILLE BEACH & 3 & 48 \\
\hline 424 & W-17602 & Core & 27.68333 & -82.73805 & PASS-A-GRILLE BEACH & 3 & 62 \\
\hline 425 & W-17979 & Core & 27.87528 & -82.74861 & SAFETY HARBOR & 19 & 138 \\
\hline 426 & W-19231 & Core & 27.88711 & -82.06303 & NICHOLS & 112 & 320 \\
\hline 427 & W-19233 & Core & 27.88714 & -82.07130 & NICHOLS & 83 & 320 \\
\hline 428 & W-19258 & Cuttings & 27.54082 & -82.07368 & DUETTE & 110 & 55 \\
\hline 429 & W-19327 & Cuttings & 27.64341 & -82.54549 & COCKROACH BAY & 5 & 1600 \\
\hline 430 & W-19660 & Core & 27.74742 & -82.12048 & DUETTE NE & 103 & 320 \\
\hline
\end{tabular}

